\title{
Measurement-model comparison of stabilized Criegee intermediate and highly oxygenated molecule production in the CLOUD chamber
}

\author{
Nina Sarnela ${ }^{1}$, Tuija Jokinen ${ }^{1}$, Jonathan Duplissy ${ }^{1}$, Chao Yan $^{1}$, Tuomo Nieminen ${ }^{2}$, Mikael Ehn ${ }^{1}$, \\ Siegfried Schobesberger ${ }^{1,2,3}$, Martin Heinritzi ${ }^{4}$, Sebastian Ehrhart ${ }^{4, a}$, Katrianne Lehtipalo ${ }^{1,5}$, Jasmin Tröstl ${ }^{5}$, \\ Mario Simon ${ }^{4}$, Andreas Kürten ${ }^{4}$, Markus Leiminger ${ }^{6}$, Michael J. Lawler ${ }^{7}$, Matti P. Rissanen ${ }^{1}$, Federico Bianchi ${ }^{1}$, \\ Arnaud P. Praplan ${ }^{8}$, Jani Hakala ${ }^{1}$, Antonio Amorim ${ }^{9}$, Marc Gonin ${ }^{10}$, Armin Hansel ${ }^{6}$, Jasper Kirkby ${ }^{4,11}$, \\ Josef Dommen $^{5}$, Joachim Curtius ${ }^{4}$, James N. Smith ${ }^{7}$, Tuukka Petäjä ${ }^{1}$, Douglas R. Worsnop ${ }^{1,12}$, Markku Kulmala ${ }^{1}$, \\ Neil M. Donahue ${ }^{13,1}$, and Mikko Sipilä ${ }^{1}$ \\ ${ }^{1}$ Institute for Atmospheric and Earth System Research/Physics, Faculty of Science, University of Helsinki, P.O. Box 64, \\ 00014 Helsinki, Finland \\ ${ }^{2}$ University of Eastern Finland, Department of Applied Physics, P.O. Box 1627, 70211 Kuopio, Finland \\ ${ }^{3}$ Department of Atmospheric Sciences, University of Washington, 408 ATG Bldg, Box 351640, Seattle, WA 98195, USA \\ ${ }^{4}$ Institute for Atmospheric and Environmental Sciences, Goethe University Frankfurt, Altenhöferallee 1, \\ 60438 Frankfurt am Main, Germany \\ ${ }^{5}$ Laboratory of Atmospheric Chemistry, Paul Scherrer Institute, 5232 Villigen PSI, Switzerland \\ ${ }^{6}$ University of Innsbruck, Institute for Ion Physics and Applied Physics, Technikerstraße 25, 6020 Innsbruck, Austria \\ ${ }^{7}$ University of California, Irvine, Department of Chemistry, Irvine, CA 92697, USA \\ ${ }^{8}$ Finnish Meteorological Institute, P.O. Box 503, 00101 Helsinki, Finland \\ ${ }^{9}$ CENTRA, Faculdade de Ciencias da Universidade de Lisboa, Lisbon, Portugal \\ ${ }^{10}$ Tofwerk AG, 3600 Thun, Switzerland \\ ${ }^{11}$ CERN, 1211 Geneva, Switzerland \\ ${ }^{12}$ Aerodyne Research, Inc., Billerica, MA 01821, USA \\ ${ }^{13}$ Carnegie Mellon University Center for Atmospheric Particle Studies, 5000 Forbes Ave, Pittsburgh, PA 15213, USA \\ anow at: Max-Planck Institute of Chemistry, Atmospheric Chemistry Department, Hahn-Meitner-Weg 1, \\ 55128 Mainz, Germany
}

Correspondence: Nina Sarnela (nina.sarnela@ @elsinki.fi)

Received: 22 August 2017 - Discussion started: 13 September 2017

Revised: 8 January 2018 - Accepted: 9 January 2018 - Published: 19 February 2018

\begin{abstract}
Atmospheric oxidation is an important phenomenon which produces large quantities of low-volatility compounds such as sulfuric acid and oxidized organic compounds. Such species may be involved in the nucleation of particles and enhance their subsequent growth to reach the size of cloud condensation nuclei (CCN). In this study, we investigate $\alpha$-pinene, the most abundant monoterpene globally, and its oxidation products formed through ozonolysis in the Cosmic Leaving OUtdoor Droplets (CLOUD) chamber at CERN (the European Organization for Nuclear Research). By scavenging hydroxyl radicals $(\mathrm{OH})$ with hydro-
\end{abstract}

gen $\left(\mathrm{H}_{2}\right)$, we were able to investigate the formation of highly oxygenated molecules (HOMs) purely driven by ozonolysis and study the oxidation of sulfur dioxide $\left(\mathrm{SO}_{2}\right)$ driven by stabilized Criegee intermediates (sCIs). We measured the concentrations of HOM and sulfuric acid with a chemical ionization atmospheric-pressure interface time-of-flight (CI-APiTOF) mass spectrometer and compared the measured concentrations with simulated concentrations calculated with a kinetic model. We found molar yields in the range of 3.5$6.5 \%$ for HOM formation and $22-32 \%$ for the formation of stabilized Criegee intermediates by fitting our model to the 
measured sulfuric acid concentrations. The simulated time evolution of the ozonolysis products was in good agreement with measured concentrations except that in some of the experiments sulfuric acid formation was faster than simulated. In those experiments the simulated and measured concentrations met when the concentration reached a plateau but the plateau was reached $20-50$ min later in the simulations. The results shown here are consistent with the recently published yields for HOM formation from different laboratory experiments. Together with the sCI yields, these results help us to understand atmospheric oxidation processes better and make the reaction parameters more comprehensive for broader use.

\section{Introduction}

Atmospheric new particle formation begins when trace gases form small molecular clusters, which can grow to larger sizes through the condensation of vapours. When they have reached a large enough diameter, these particles can act as cloud and ice condensation nuclei that may affect the optical properties of clouds or have other effects on climate and air quality, such as a decrease in visibility. A lot of effort has been put into identifying the vapours responsible for the nucleation and growth of the particles. Various studies have identified sulfuric acid and low-volatility organic compounds as the key compounds in atmospheric new particle formation (Bianchi et al., 2016; Kirkby et al., 2016; Riccobono et al., 2014; Riipinen et al., 2011; Sihto et al., 2006; Tröstl et al., 2016; Weber et al., 1997; Wehner et al., 2005). Other important aerosol precursors identified in several laboratory studies include ammonia and amines (Almeida et al., 2013; Ball et al., 1999; Murphy et al., 2007). Laboratory measurements (Almeida et al., 2013; Berndt et al., 2010, 2014b; Jen et al., 2014; Kirkby et al., 2011) and computational studies (Kurtén et al., 2008; Paasonen et al., 2012) suggest that ammonia and amines can enhance particle formation but it is challenging to estimate their importance in the ambient atmosphere without comprehensive measurements of their concentration in the atmosphere. Neutral sulfuric acid-amine clusters have been observed in the CLOUD chamber experiments (Kürten et al., 2014) but similar neutral clusters have not yet been detected in the atmosphere. Field studies suggest that iodine oxides could be the key compounds for new particle formation in coastal areas during periods when high tidal movements expose algae beds to sunlight (O'Dowd et al., 2002; Sipilä et al., 2016). However, these iodine oxides do not appear as abundantly in the atmosphere as sulfuric acid or low-volatility organic vapours, so their importance seem to be limited to coastal areas.

Sulfuric acid is linked with new particle formation events all around the world (Kulmala et al., 2004). Gas-phase sulfuric acid was previously thought to be formed solely via OH-radical oxidation of sulfur dioxide $\left(\mathrm{SO}_{2}\right)$ and dimethyl- sulfide (Lucas and Prinn, 2005). However, stabilized Criegee intermediates (sCIs), formed in a reaction between unsaturated hydrocarbons and ozone, are also capable of oxidizing $\mathrm{SO}_{2}$ into sulfuric acid. While sCIs (Chuong et al., 2004; Donahue et al., 2011; Drozd and Donahue, 2011) and their reactions with $\mathrm{SO}_{2}$ (Cox and Penkett, 1971) have been investigated for decades, the potential of the atmospheric relevance of sCI $+\mathrm{SO}_{2}$ was demonstrated more recently (Berndt et al., 2012; Mauldin III et al., 2012; Welz et al., 2012). In the reaction between ozone and alkenes, a primary ozonide is formed which decomposes quickly to a carbonyl and a carbonyl oxide known as the Criegee intermediate (Criegee, 1975). A fraction of the Criegee intermediates can be collisionally stabilized to form sCI (Donahue et al., 2011; Herron et al., 1982). In the case of $\alpha$-pinene and other endocyclic alkenes, both functional groups - the carbonyl and Criegee intermediate - remain in the same molecule. Recent studies indicate that $\mathrm{sCI}$ can have a significant role in ambient sulfuric acid formation (Boy et al., 2013; Welz et al., 2012; Yao et al., 2014). Determining the reaction rate constants for $\mathrm{sCI}+\mathrm{SO}_{2}$ reactions has been challenging and the previous estimates have varied considerably due to the lack of direct measurements of SCI compounds (Johnson and Marston, 2008). Recent studies (Berndt et al., 2012; Mauldin III et al., 2012; Welz et al., 2012) with new experimental methods have shown reaction rate constants up to 4 orders of magnitude higher for the reaction between an $\mathrm{SCI}$ and $\mathrm{SO}_{2}$ compared to previous estimates. Differences between the reactivity of sCI derived from different alkenes and their reactivity towards $\mathrm{SO}_{2}$, water and several other atmospheric compounds have also been emphasized (Berndt et al., 2014a; Sipilä et al., 2014; Taatjes et al., 2013; Vereecken et al., 2012, 2014).

The other important reaction pathway associated with the ozonolysis of alkenes, such as $\alpha$-pinene, is the formation of highly oxygenated molecules (HOMs; Ehn et al., 2012; Kirkby et al., 2016; Tröstl et al., 2016). Crounse et al. (2013) suggested that autoxidation, in which the radicals produced after the initial oxidation are oxidized by atmospheric oxygen, plays an important role in the atmospheric oxidation of organic compounds. Organic radicals, including radicals formed when Criegee intermediates decompose, will react with molecular oxygen $\left(\mathrm{O}_{2}\right)$ to form a peroxy radical $\left(\mathrm{RO}_{2}\right)$. The $\mathrm{RO}_{2}$ can subsequently undergo an intramolecular $\mathrm{H}$ shift, which will be followed by subsequent $\mathrm{O}_{2}$ addition to form a more oxidized $\mathrm{RO}_{2}$. According to the mechanism introduced by Ehn et al. (2014), the $\mathrm{RO}_{2}$ can undergo several additional reactions with $\mathrm{O}_{2}$, which eventually leads to the formation of HOM, also referred to as extremely low-volatility organic compounds (ELVOCs; Donahue et al., 2012; Ehn et al., 2014; Jokinen et al., 2015) or highly oxidized multifunctional organic compounds (HOMs; Ehn et al., 2012). Here we call them HOMs, as it was recently recognized that not all HOMs are necessarily extremely low volatility (Tröstl et al., 2016). The $\mathrm{RO}_{2}$ can also react with 
Table 1. Description of different experimental systems compared in this study.

\begin{tabular}{lrrr}
\hline & $\begin{array}{r}\text { TROPOS-LFT } \\
\text { TROPOS Laminar Flow Tube; } \\
\text { Leipzig, Germany } \\
\text { (Berndt et al., 2005) }\end{array}$ & $\begin{array}{r}\text { JPAC } \\
\text { Chamber; Jülich, Germany } \\
\text { (Mentel et al., 2009) }\end{array}$ & $\begin{array}{r}\text { CLOUD } \\
\text { Droplets; Geneva, Switzerland } \\
\text { (Kirkby et al., 2011) }\end{array}$ \\
\hline Description & $\begin{array}{r}\text { Laminar flow glass tube } \\
\text { with 40 s residence time }\end{array}$ & $\begin{array}{r}\text { Borosilicate glass chamber } \\
\text { with } 45 \text { min residence time }\end{array}$ & $\begin{array}{r}\text { Stainless steel chamber } \\
\text { with 3 h residence time }\end{array}$ \\
\hline Volume & $0.025 \mathrm{~m}^{3}$ & $1.45 \mathrm{~m}^{3}$ & $26.1 \mathrm{~m}^{3}$ \\
Temperature & $293 \mathrm{~K}$ & $289 \mathrm{~K}$ & $278 \mathrm{~K}$ \\
RH & $25-50 \%$ & $63 \%$ & $38 \%$ \\
Wall loss & $10-27 \%$ & $11 \times 10^{-3} \mathrm{~s}^{-1}$ & $1.2-1.9 \times 10^{-3} \mathrm{~s}^{-1}$ \\
OH scavenger & $\mathrm{H}_{2}$, propane & & $\mathrm{H}_{2}$ \\
\hline
\end{tabular}

nitrogen monooxide (NO), the hydroperoxyl radical $\left(\mathrm{HO}_{2}\right)$ or another $\mathrm{RO}_{2}$, which can terminate the autoxidation reaction chain and form a closed-shell product. The molar yield of HOM formed from $\alpha$-pinene and ozone is reported to be around 3-7 \% (Ehn et al., 2014; Jokinen et al., 2015; Kirkby et al., 2016).

In Earth's atmosphere $\alpha$-pinene is the most abundant monoterpene having yearly emissions of $50 \mathrm{Tg}$ globally (Guenther et al., 1995; Seinfeld and Pankow, 2003), and around $80 \%$ of the emitted $\alpha$-pinene undergoes oxidation via ozonolysis (Griffin et al., 1999). The high yields of HOMs acting as condensing vapours can explain a large portion of the formed secondary organic aerosol (SOA), at least in forested regions. At atmospheric pressure, ozonolysis of the endocyclic $\alpha$-pinene generates sCI with a low but important yield, measured to be around 15\% (15\%, Drozd and Donahue, 2011, $15 \pm 7 \%$; Sipilä et al., 2014).

In this study we conducted pure ozonolysis experiments in which $\mathrm{OH}$ was removed by molecular hydrogen $\left(\mathrm{H}_{2}\right)$ used as a scavenger in the CLOUD chamber facility at CERN (Kirkby et al., 2011; Duplissy et al., 2016) during the CLOUD7 campaign in fall 2012. We examined the formation of sulfuric acid originating from Criegee intermediate oxidation and of HOM from $\alpha$-pinene oxidation and compared the temporal trends of the measured to the modelled concentrations. The modelling of HOM concentration was based on the experimental yield terms obtained from recent studies by Ehn et al. (2014) and Jokinen et al. (2015), while the sulfuric acid concentration was modelled using the reaction coefficient and the yield term from the study by Sipilä et al. (2014). In addition, we calculated the yield terms for sCI and HOM formation in the CLOUD experiments by fitting our model to the measured sulfuric acid and HOM concentrations.

\section{Methods}

\subsection{Experiments}

We conducted the experiments in the CLOUD chamber, which is a $26.1 \mathrm{~m}^{3}$ electro-polished stainless steel cylinder at CERN (Geneva, Switzerland; Kirkby et al., 2011; Duplissy et al., 2016). We compared our results to previous experiments of $\alpha$-pinene ozonolysis conducted in the TROPOS Laminar Flow Tube (Berndt et al., 2005) and the Jülich Plant Atmosphere Chamber facility (Mentel et al., 2009; Table 1). In contrast to these experimental facilities, the CLOUD chamber has a smaller wall loss rate (e.g. around $1.8 \times 10^{-3} \mathrm{~s}^{-1}$ for sulfuric acid), which is similar to the condensation sink in relatively unpolluted ambient environments. This feature allows us to investigate nucleation and growth processes with precursors at atmospherically relevant concentrations.

For this study, only $\alpha$-pinene ozonolysis experiments fulfilling certain conditions were selected:

- only ozone, $\alpha$-pinene and sulfur dioxide were added as precursors to the chamber;

- $\mathrm{H}_{2}$ was used as an $\mathrm{OH}$ scavenger;

- ions were constantly removed from the chamber (i.e. neutral conditions); and

- $38 \%$ relative humidity and $278 \mathrm{~K}$ temperature were maintained.

We used two electrodes operating at voltages of $\pm 30 \mathrm{kV}$ inside the chamber to produce an electric field of $20 \mathrm{kV} \mathrm{m}^{-1}$ throughout the chamber, which removed all the ions in order to maintain neutral conditions. All the experiments were done at $278 \mathrm{~K}$ and the thermal insulation kept the temperature stable within $0.05 \mathrm{~K}$ (Duplissy et al., 2016). The relative humidity was kept at $38 \%$ during all the experiments. The synthetic air used in the chamber was provided from cryogenic liquid $\mathrm{N}_{2}$ and $\mathrm{O}_{2}(79: 21$ volume ratio) and $0.1 \%$ of $\mathrm{H}_{2}$ was added to the air to scavenge all the hydroxyl radicals $(\mathrm{OH})$ and prevent any $\mathrm{OH}$-initiated reactions. The ozone 
Table 2. The measured concentrations of precursor vapours (ozone, $\alpha$-pinene and sulfur dioxide), formation rates at $2.5 \mathrm{~nm}$, growth rates of particles smaller than $3 \mathrm{~nm}$ and calculated yields for sCI and HOM during the experiments.

\begin{tabular}{rrrrrrrr}
\hline & $\begin{array}{r}\mathrm{O}_{3} \\
(\mathrm{ppbv})\end{array}$ & $\begin{array}{r}\alpha \text {-pinene } \\
(\mathrm{pptv})\end{array}$ & $\begin{array}{r}\mathrm{SO}_{2} \\
(\mathrm{ppbv})\end{array}$ & $\begin{array}{r}\text { Formation rate } \\
\left(\mathrm{cm}^{-3} \mathrm{~s}^{-1}\right)\end{array}$ & $\begin{array}{r}\text { Growth rate } \\
\left(\mathrm{nm} \mathrm{h}^{-1}\right)\end{array}$ & $\begin{array}{r}\text { sCI yield } \\
(\%)\end{array}$ & $\begin{array}{r}\mathrm{HOM} \text { yield } \\
(\%)\end{array}$ \\
\hline 1 & 22 & 80 & 72 & 13.26 & 1.88 & 22 & 5 \\
2 & 24 & 80 & 72 & $9.11 \times 10^{-2}$ & 1.50 & 22 & 3.5 \\
3 & 22 & 600 & 67 & 47.98 & 7.21 & 23 & 6 \\
4 & 22 & 170 & 68 & 3.95 & 2.32 & 24 & 5.5 \\
5 & 22 & 530 & 17 & 18.10 & 3.77 & 32 & 6.5 \\
\hline
\end{tabular}

mixing ratio was kept around $22 \mathrm{ppbv}$ in all the experiments. Sulfur dioxide was added to the chamber at a mixing ratio of around $70 \mathrm{ppbv}$ in four experiments and at a mixing ratio of $17 \mathrm{ppbv}$ in one experiment. $\alpha$-Pinene was supplied with mixing ratios varying between 80 and 600 pptv from a temperature-controlled evaporator using $\mathrm{N}_{2}$ as a carrier gas. Two counter-rotating stainless steel fans are mounted inside the chamber to achieve efficient turbulent mixing of the gases and ions (Voigtländer et al., 2012). The total flow through the chamber is kept constant during the experiments.

We started the ozonolysis experiments with a constant concentration of $\mathrm{SO}_{2}, \mathrm{O}_{3}$ and $\mathrm{H}_{2}$ in the chamber (background measurement). Then we injected $\alpha$-pinene into the chamber with a constant flow rate during the whole experiment (4-7 h). In between the experiments, the chamber was cleaned by closing the $\alpha$-pinene flow and flushing the chamber with pure air (mixture of evaporated liquid nitrogen and liquid oxygen). All particles formed were removed by repeatedly charging the particles and applying the high-voltage clearing electric field inside the chamber. The conditions of each experiment are shown in Table 2.

\subsection{Instruments}

A proton transfer reaction mass spectrometer (PTR-MS; Ionicon Analytik GmbH; Lindinger et al., 1998) was used to measure the concentrations of volatile organic compounds (including $\alpha$-pinene). The neutral particle size distribution of $2-40 \mathrm{~nm}$ particles was measured with a neutral cluster and air ion spectrometer (NAIS; Mirme and Mirme, 2013). The particle size distribution of $5-80 \mathrm{~nm}$ particles was measured with a nano scanning mobility particle sizer (nanoSMPS; Wang and Flagan, 1990) and the condensation sink due to particles in the chamber was calculated from the size distribution. Sulfur dioxide concentration was measured with a high-sensitivity pulse fluorescence analyser (model 43i-TLE; Thermo Fisher Scientific), and ozone with a UV photometric ozone analyser (model 49C; Thermo Environmental Instruments).

The gas-phase sulfuric acid and HOMs were detected with a nitrate-ion-based chemical ionization atmospheric-pressure interface time-of-flight mass spectrometer (nitrate-CI-APiTOF; Tofwerk AG, Thun, Switzerland and Aerodyne Re- search Inc., USA; Jokinen et al., 2012; Junninen et al., 2010). A soft X-ray source (Hamamatsu L9490) was deployed to ionize nitric acid to nitrate ions $\left(\left(\mathrm{HNO}_{3}\right)_{0-2} \mathrm{NO}_{3}^{-}\right)$, which were used as the reagent ions for the chemical ionization. The ionization method is selectively suited for detecting strong acids such as sulfuric acid or methane sulfonic acid (Eisele and Tanner, 1993). The case of the oxidized organic compounds requires molecules to have at least two hydroperoxy $(\mathrm{OOH})$ groups or some other $\mathrm{H}$-bond-donating groups to be ionized (Hyttinen et al., 2015). A previous study of cyclohexene ozonolysis showed that in contrast to highly oxygenated products such as $\mathrm{C}_{6} \mathrm{H}_{8} \mathrm{O}_{7}$ and $\mathrm{C}_{6} \mathrm{H}_{8} \mathrm{O}_{9}$ (with three carbonyl groups and two and three hydroperoxy groups, respectively), products like $\mathrm{C}_{6} \mathrm{H}_{8} \mathrm{O}_{5}$ (three carbonyl groups and one hydroperoxy group) could not be detected (Rissanen et al., 2014). However, in previous $\alpha$-pinene experiments oxidized products with an $\mathrm{O}: \mathrm{C}$ ratio of as low as 0.6 have been detected (Jokinen et al., 2015; Praplan et al., 2015).

The concentration of sulfuric acid was calculated according to Eq. (1), in which a calibration coefficient $c$ is applied on the count rates of the bisulfate ion and its cluster with nitric acid normalized to the sum of count rates of reagent ions (Jokinen et al., 2012). To obtain the calibration coefficient $c$, the instrument was calibrated for sulfuric acid with a calibration set-up described by Kürten et al. (2012). The calibration constant was measured to be $5 \times 10^{9}$ molecules $\mathrm{cm}^{-3}$. Taking sample tube losses into account a value of $1.25 \times 10^{10}$ molecules $\mathrm{cm}^{-3}$ was obtained for $c$.

$$
\left[\mathrm{H}_{2} \mathrm{SO}_{4}\right]=\frac{\mathrm{HSO}_{4}^{-}+\left(\mathrm{HNO}_{3}\right) \mathrm{HSO}_{4}^{-}}{\mathrm{NO}_{3}^{-}+\left(\mathrm{HNO}_{3}\right) \mathrm{NO}_{3}^{-}+\left(\mathrm{HNO}_{3}\right)_{2} \mathrm{NO}_{3}^{-}} \cdot c
$$

In the experiments the concentration of sulfuric acid clusters was low since there were no stabilizing agents such as amines or ammonia added into the chamber. Thus the vast majority of the sulfuric acid concentration was in the form of a monomer, not in the clusters as "hidden sulfuric acid" (Rondo et al., 2016). At most, less than $2 \%$ of the total sulfuric acid concentration was involved in the clusters, while most of the time no sulfuric acid clusters were detected. 


\subsection{Estimation of HOM sensitivity}

In this study, we counted all the $\alpha$-pinene oxidation products that were detected and identified with nitrate-CI-APi-TOF as HOM. The total concentration of HOM was calculated by summing up the high-resolution fitted signals of identified highly oxygenated compounds (see the full list of peaks in Appendix A). These compounds were detected in the range of 220-620 Th and their $\mathrm{O}: \mathrm{C}$ ratios were between 0.6 and 1.3. Most of the elemental compositions found in the experiments were the same as have been published by Ehn et al. (2012) and Jokinen et al. (2014). The sum of signals was divided by the sum of reagent ion signals and multiplied by the same calibration constant that was used for sulfuric acid (Eq. 2).

$$
[\mathrm{HOM}]=\frac{\sum \mathrm{HOM} \cdot \mathrm{NO}_{3}^{-}}{\mathrm{NO}_{3}^{-}+\left(\mathrm{HNO}_{3}\right) \mathrm{NO}_{3}^{-}+\left(\mathrm{HNO}_{3}\right)_{2} \mathrm{NO}_{3}^{-}} \cdot c
$$

Since we did not have a direct calibration method for HOM, we considered three additional terms which may affect the detection of molecules before the calibration constant of sulfuric acid can be used (Eq. 3; Kürten et al., 2014).

$$
\begin{aligned}
& {[\mathrm{HOM}]=\frac{k_{\mathrm{SA}}}{k_{\mathrm{HOM}}} \cdot \frac{T_{\mathrm{SA}}}{T_{\mathrm{HOM}}} \cdot \frac{e_{\mathrm{SA}}}{e_{\mathrm{HOM}}}} \\
& \cdot \frac{\sum \mathrm{HOM} \cdot \mathrm{NO}_{3}^{-}}{\mathrm{NO}_{3}^{-}+\left(\mathrm{HNO}_{3}\right) \mathrm{NO}_{3}^{-}+\left(\mathrm{HNO}_{3}\right)_{2} \mathrm{NO}_{3}^{-}} \cdot c
\end{aligned}
$$

The first term $k_{\mathrm{SA}} / k_{\mathrm{HOM}}$ corrects for the difference in reaction rate between the HOM and the reagent ions compared to sulfuric acid and the reagent ions. In the chemical ionization method, there is an excess of nitric acid in the drift tube where the sample flow and reagent ions meet. The nitrate dimer, $\mathrm{HNO}_{3} \mathrm{NO}_{3}^{-}$, is an extremely stable cluster, which means that if there are some other clusters forming with $\mathrm{NO}_{3}^{-}$ in the drift tube, they need to be even more stable than the nitrate dimer. As we can detect a large total signal of HOMnitrate clusters, we can assume that they are very stable. If we assume that all the HOMs that collide with nitrate ions in the drift tube form clusters and stick together subsequently, we get the lower limit of HOM concentration from our measurements. If all collisions did not in reality produce clusters or if some fraction of the clusters decomposed in the drift tube or inside the high-vacuum region of the TOF, the real concentrations of HOM would be higher than assumed by this method. Ehn et al. (2014) reported calculated collision-limited reaction rates of $k_{\mathrm{HOM}}=(1.5-2.8) \times 10^{-9} \mathrm{~cm}^{3} \mathrm{~s}^{-1}$ for HOM and $k_{\mathrm{SA}}=(1.5-2.5) \times 10^{-9} \mathrm{~cm}^{3} \mathrm{~s}^{-1}$ for sulfuric acid. To achieve these values Ehn et al. (2014) used the formulation of Su and Bowers (Su and Bowers, 1973) and assumed some possible structures of $\mathrm{HOM}$ and calculated the collision frequencies of nitrate clusters $\left(\mathrm{HNO}_{3}\right)_{0-2} \mathrm{NO}_{3}^{-}$with selected $\mathrm{HOM}$ and sulfuric acid. The collision-limited reaction rates are so close to each other that we approximated the term $k_{\mathrm{SA}} / k_{\mathrm{HOM}}$ to be 1.
The second term $T_{\mathrm{SA}} / T_{\mathrm{HOM}}$ describes the differences in the transmission efficiency of different-sized molecules or clusters through the sampling line, as the increasing size of the molecule or cluster implies smaller diffusivity. A third term $e_{\mathrm{SA}} / e_{\mathrm{HOM}}$ takes into account the mass discrimination effects inside the mass spectrometer. The total effect of the terms $T_{\mathrm{SA}} / T_{\mathrm{HOM}}$ and $e_{\mathrm{SA}} / e_{\mathrm{HOM}}$ was determined experimentally with a high-resolution differential mobility analyser (HR-DMA; Junninen et al., 2010). With this method, trioctylmethylammonium bis(trifluoromethylsulfonyl)imide particles were produced with an electrospray, and size ranges were selected with a high-resolution Vienna-type differential mobility analyser (UDMA; Steiner et al., 2010); the selected size range was guided to the APi-TOF. To calculate the transmission the signal in the mass spectrometer was divided by the signal in the electrometer. The transmission in the mass range between 90 and $600 \mathrm{Th}$ varied so that the largest difference compared to the transmission of sulfuric acid was 1.4 -fold at $320 \mathrm{Th}\left(7.3 \times 10^{-4}\right)$. Since HOM could be measured over a wide mass range, the transmission varied between individual HOM molecules $\left((6.4-10.4) \times 10^{-4}\right)$. The averaged difference in the transmissions was around $30 \%$ so that the transmission of HOM signals was higher than the sulfuric acid signals, and this was taken into account in the concentration calculations by correcting the values according the transmission curve.

We estimated a systematic uncertainty of $+50 \%$ to $-33 \%$ for the sulfuric acid concentration (Kirkby et al., 2016). The estimation is based on the uncertainty of the sulfuric acid calibration and a comparison with the sulfuric acid concentration measured by another CIMS instrument (independently measured sulfuric acid concentration in CLOUD experiments; Kürten et al., 2011). For the HOM concentration the uncertainty is larger due to lack of a direct calibration method. We estimated an uncertainty of $+80 \%$ to $-45 \%$ for HOM concentrations taking the sulfuric acid calibration, charging efficiency, mass-dependent transmission efficiency calibration and sampling line losses into consideration (Jokinen et al., 2015; Kirkby et al., 2016). The uncertainty for HOM yield arises from the uncertainties of $\alpha$-pinene concentration, $\mathrm{O}_{3}$ concentration, $\mathrm{HOM}$ wall loss rate and rate constants. This results in a mean estimated uncertainty in HOM yield of $+100 \%$ to $-60 \%$.

\subsection{The simulations of $\mathrm{SCI}$ and HOM concentrations}

The temporal behaviour of the reaction products from monoterpene ozonolysis in the CLOUD chamber was simulated with a 0-dimensional kinetic model. The production of stabilized Criegee intermediates was calculated from the measured $\alpha$-pinene and ozone concentrations using a reaction rate coefficient of $8.05 \times 10^{-17} \mathrm{~cm}^{3} \mathrm{~s}^{-1}$ (Atkinson et al., 2006; updated data sheet can be found at http://iupac.pole-ether.fr/htdocs/datasheets/pdf/Ox VOC8_O3_apinene.pdf). Since the temperature of CLOUD 
experiments was lower than in previous experiments done in TROPOS-LFT and JPAC (Table 1) we used a lower reaction rate coefficient $\left(8.66 \times 10^{-17} \mathrm{~cm}^{3} \mathrm{~s}^{-1}\right.$ in JPAC experiments and $1.1 \times 10^{-16} \mathrm{~cm}^{3} \mathrm{~s}^{-1}$ in TROPOS-LFT experiments). The reaction of $\mathrm{sCI}$ with $\mathrm{SO}_{2}$ is in competition with the reaction of sCI with water vapour; thus, three loss paths were taken into account for the sCI: (1) its reaction with sulfur dioxide $\left(k_{\mathrm{SCI}}+\mathrm{SO}_{2}\right),(2)$ the thermal decomposition of $\mathrm{sCI}\left(k_{\mathrm{dec}}\right)$ and (3) its reaction with water vapour $\left(k_{\mathrm{SCI}}+\mathrm{H}_{2} \mathrm{O}\right)$. The latter two reactions are included in the loss term $k_{\text {loss }}(\mathrm{Eq} .4)$ and under these conditions thermal decomposition dominates the loss mechanism of $\mathrm{sCI}$ and the reaction with water vapour is less important. The condensation sink, wall loss and dilution are negligible compared to the loss term $k_{\text {loss }}$. The reaction rate of sCI and water vapour has been found to strongly depend on the structure of the Criegee intermediate (Berndt et al., 2014c; Huang et al., 2015), and for the monoterpenederived sCIs, the relative rate coefficient $k_{\text {loss }} / k_{\mathrm{SCI}+\mathrm{SO}_{2}}$ was found to be nearly independent of the relative humidity (Sipilä et al., 2014). The kinetic study of Huang et al. (2015) suggested that sCIs with more complicated substitution groups (such as $\alpha$-pinene-derived sCIs) react with water slowly but react with $\mathrm{SO}_{2}$ quickly, thus supporting the reaction parameters achieved by Sipilä et al. (2014). Other possible loss paths of sCI are considered to be negligible. The studies of Vereecken et al. $(2012,2014)$ show that a high substitution of $\mathrm{CI}$ and/or the reaction partner results in strong steric hindrance between the substituents, which effectively inhibits reactions between them. Thus, reactions between monoterpene-derived sCI and SVOCs are not favourable.

$$
\begin{aligned}
& k_{\text {loss }}=k_{\text {dec. }}+\left(k_{\left(\mathrm{sCI}+\mathrm{H}_{2} \mathrm{O}\right)} \cdot\left[\mathrm{H}_{2} \mathrm{O}\right]\right) \\
& \frac{\mathrm{d}[\mathrm{sCI}]}{\mathrm{d} t}=\left(Y_{\mathrm{sCI}} \cdot k_{\mathrm{O}_{3}+\alpha \text {-pinene }} \cdot\left[\mathrm{O}_{3}\right] \times[\alpha \text {-pinene }]\right) \\
& \quad-\left(k_{\text {loss }} \cdot[\mathrm{sCI}]\right)-\left(k_{\mathrm{SCI}+\mathrm{SO}_{2}} \cdot\left[\mathrm{SO}_{2}\right] \cdot[\mathrm{sCI}]\right)
\end{aligned}
$$

The concentration of sCI was calculated according to Eq. (5), in which the values of the reaction rate coefficient $\left(k_{\mathrm{SCI}}+\mathrm{SO}_{2}\right)$, the sCI yield term $\left(Y_{\mathrm{SCI}}\right)$ and the loss term $\left(k_{\text {loss }}\right)$ were taken from the TROPOS-LFT measurements (Sipilä et al., 2014). Those measurements were conducted at $50 \%$ relative humidity (RH) and the derived sCI yield from the reaction between $\alpha$-pinene and ozone was determined to be $0.15 \pm$ 0.07 ; the ratio between the loss term and $k_{\mathrm{SCI}+\mathrm{SO}_{2}}$ was $(2.0 \pm 0.4) \times 10^{12}$ molecules $\mathrm{cm}^{-3}$. Sipilä et al. (2014) also found that in the case of $\alpha$-pinene and limonene the ratio $k_{\text {loss }} / k_{\mathrm{SCI}}+\mathrm{SO}_{2}$ was nearly independent of the relative humidity. Therefore we neglected the difference in RH of the experiments shown here $(38 \%)$ compared to the experiments at TROPOS-LFT $(50 \%)$. The temperature was $278 \mathrm{~K}$ in the CLOUD experiments, whereas it was $293 \mathrm{~K}$ in the previous experiments. The influence of temperature on the $\mathrm{H}_{2} \mathrm{SO}_{4}$ formation from the gas-phase reaction of monoterpene-derived $\mathrm{sCIs}$ has not yet been investigated. It is very likely that $k_{\mathrm{dec}}$ is higher at higher temperatures, which would cause under- estimation of the sulfuric acid concentration in the CLOUD simulations, for which we are using the loss term derived from experiments performed at higher temperature. In the sCI yield experiments performed with acetone oxide the temperature influence on the ratio of $k_{\mathrm{dec}} / k_{\mathrm{SCI}}+\mathrm{SO}_{2}$ was 2fold when the temperature was increased by $10 \mathrm{~K}$ (Berndt et al., 2014c).

The lower and upper limits of the sCI concentration were modelled with the upper and lower values for the yield and loss term so that the lower limit was calculated with a yield of $8 \%$ and a $k_{\text {loss }} / k_{\mathrm{SCI}+\mathrm{SO}_{2}}$ ratio of $2.4 \times 10^{12}$ molecules $\mathrm{cm}^{-3}$, while the upper limit was calculated with a yield of $22 \%$ and a $k_{\text {loss }} / k_{\mathrm{sCI}+\mathrm{SO}_{2}}$ ratio of $1.6 \times 10^{12}$ molecules $\mathrm{cm}^{-3}$ (Eq. 5). For the calculations we needed to separate the terms $k_{\text {loss }}$ and $k_{\mathrm{SCI}+\mathrm{SO}_{2}}$ from each other. As long as the ratio between the terms stays the same, the chosen values do not make a difference for the sulfuric acid concentration.

The concentration of sulfuric acid in the CLOUD chamber was modelled according to Eq. (6).

$$
\begin{gathered}
\frac{\mathrm{d}\left[\mathrm{H}_{2} \mathrm{SO}_{4}\right]}{\mathrm{d} t}=k_{\mathrm{SCI}+\mathrm{SO}_{2}} \cdot[\mathrm{sCI}] \cdot\left[\mathrm{SO}_{2}\right] \\
-\left(\mathrm{CS}+k_{\text {wall_loss }}+k_{\mathrm{dil}}\right) \cdot\left[\mathrm{H}_{2} \mathrm{SO}_{4}\right]
\end{gathered}
$$

As an $\mathrm{OH}$ scavenger was used in the experiments, the only formation pathway for sulfuric acid was assumed to be the reaction between the $\mathrm{SCI}$ and $\mathrm{SO}_{2}$. The production of sulfuric acid was calculated with the modelled sCI concentration, measured sulfur dioxide concentration and the reaction coefficient $k_{\mathrm{SCI}+\mathrm{SO}_{2}}$ (Sipilä et al., 2014). The sulfur dioxide and ozone concentrations were kept constant during the experiments. Three loss processes were taken into account for sulfuric acid: the condensation sink (CS), the wall loss $\left(k_{\text {wall loss }}\right)$ and the dilution $\left(k_{\mathrm{dil}}\right)$. The lifetime of sulfuric acid with respect to wall loss in the CLOUD chamber has been measured to be around 550 s (Almeida et al., 2013; Duplissy et al., 2016; Rondo et al., 2014). The dilution rate due to the injection of make-up gases into the chamber was $0.1 \times 10^{-3} \mathrm{~s}^{-1}$.

The production rate of HOM in the CLOUD chamber (Eq. 7) was calculated from the measured $\alpha$-pinene and ozone concentrations, a reaction rate coefficient of $8.05 \times$ $10^{-17} \mathrm{~cm}^{3} \mathrm{~s}^{-1}$ (Atkinson et al., 2006) and an experimentally derived yield term (Ehn et al., 2014; Jokinen et al., 2015). The yield of HOM from the reaction between $\alpha$-pinene and ozone was reported in recent studies. Ehn et al. (2014) obtained a yield of $7 \pm 3.5 \%$ in their experiments in the Jülich Plant Atmosphere Chamber, while Jokinen et al. (2015) calculated a yield of $3.4 \%$ with an estimated uncertainty of -1.7 to $+3.4 \%$ from the experiments done in the TROPOSLFT, and Kirkby et al. (2016) reported a yield of $2.9 \%$ for the CLOUD experiments with and without ions. The same loss paths were taken into account in the modelled HOM concentration as for the sulfuric acid concentration. The lifetime of HOM was measured to be around $900 \mathrm{~s}$, which is longer 

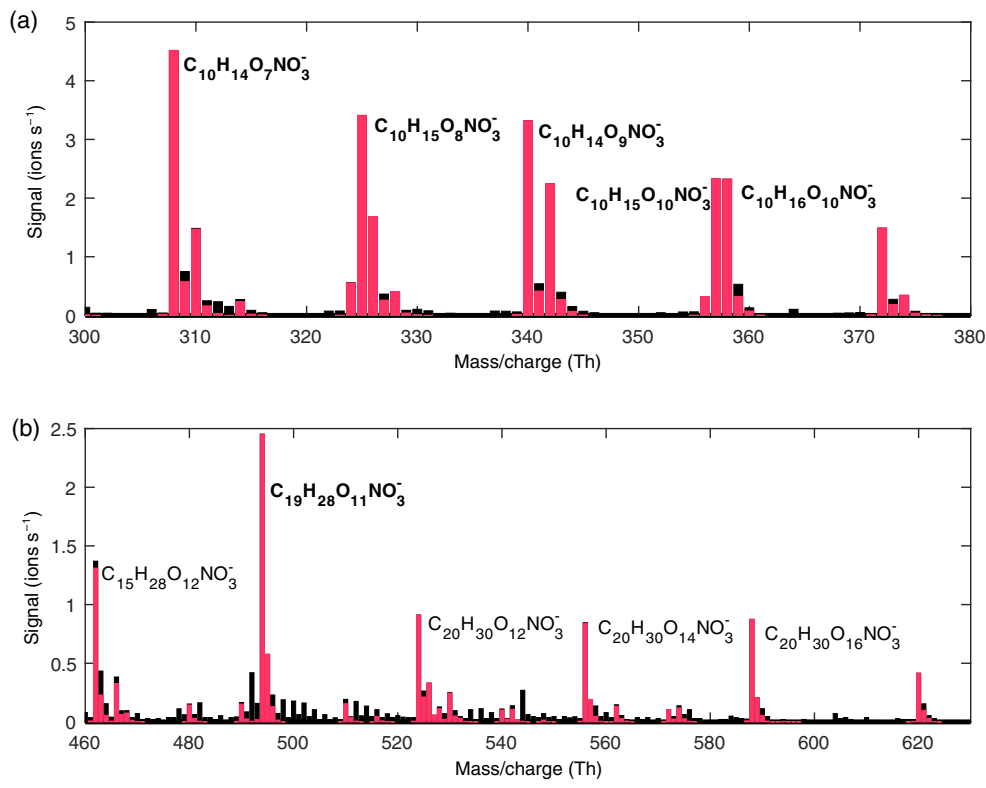

Figure 1. HOM mass spectrum during an $\alpha$-pinene ozonolysis experiment ( $\mathrm{C} 10$ compounds in panel a and $\mathrm{C} 20$ compounds in panel b). The measured mass spectrum is depicted in black and the compounds identified as HOMs are depicted in red. The elemental composition of the compounds with the highest concentrations are shown in the figure and the six most abundant compounds are labelled in bold.

Table 3. Reaction rates, loss terms and yields used in simulations.

\begin{tabular}{lr}
\hline$k_{\text {loss }} / k_{\mathrm{SCI}}+\mathrm{SO}_{2}$ & $(1.6-2.4) \times 10^{12}$ molecules cm $^{-3}$ \\
$k_{\mathrm{O}_{3}+\alpha \text {-pinene }}$ & $8.05 \times 10^{-17} \mathrm{~cm}^{3} \mathrm{~s}^{-1}$ \\
$Y_{\mathrm{SCI}}$ (Sipilä et al., 2014) & $0.08-0.22$ \\
$k_{\text {wall loss (SA) }}$ & $1.8 \times 10^{-3} \mathrm{~cm}^{3} \mathrm{~s}^{-1}$ \\
$k_{\text {wall loss (HOM) }}$ & $1.1 \times 10^{-3} \mathrm{~cm}^{3} \mathrm{~s}^{-1}$ \\
$k_{\text {dil }}$ & $0.1 \times 10^{-3} \mathrm{~cm}^{3} \mathrm{~s}^{-1}$ \\
$Y_{\mathrm{HOM}}$ (Ehn et al., 2014) & $0.035-0.105$ \\
$Y_{\mathrm{HOM}}$ (Jokinen et al., 2014) & $0.017-0.068$ \\
\hline
\end{tabular}

than the lifetime of sulfuric acid (Kirkby et al., 2016). All the values used in the modelling of sulfuric acid and HOM concentrations are shown in Table 3.

$$
\begin{aligned}
& \frac{\mathrm{d}[\mathrm{HOM}]}{\mathrm{d} t}=Y_{\mathrm{HOM}} \times k_{\mathrm{O}_{3}+\alpha-\text { pinene }} \cdot\left[\mathrm{O}_{3}\right] \cdot[\alpha-\text { pinene }] \\
& -\left(\mathrm{CS}+k_{\mathrm{wall} \_ \text {loss }}+k_{\mathrm{dil}}\right) \cdot[\mathrm{HOM}]
\end{aligned}
$$

\section{Results}

\subsection{Reaction products from $\alpha$-pinene ozonolysis}

During the ozonolysis experiments of $\alpha$-pinene, a simultaneous increase in the concentrations of sulfuric acid and HOM was observed. Several highly oxidized $\alpha$-pinene oxidation products were observed between 220 and $620 \mathrm{Th}$ (Fig. 1). All the HOMs were detected as clusters with a nitrate ion $\left(\mathrm{NO}_{3}^{-}\right)$.
As a result of the high cleanliness of the CLOUD chamber, the mass spectra consist mainly of the oxidation products and concentrations of contaminants were low. The most abundant HOM monomers, containing a $\mathrm{C}_{10}$ carbon skeleton, had an $\mathrm{O}: \mathrm{C}$ ratio between 0.7 and 1.1 , whereas the most abundant HOM dimers, containing a $\mathrm{C}_{20}$ carbon skeleton, had an $\mathrm{O}: \mathrm{C}$ ratio around $0.6-0.8$. The highest concentrations were observed from compounds identified as $\mathrm{C}_{10} \mathrm{H}_{14} \mathrm{O}_{7}, \mathrm{C}_{10} \mathrm{H}_{15} \mathrm{O}_{8}$, $\mathrm{C}_{10} \mathrm{H}_{14} \mathrm{O}_{9}, \mathrm{C}_{10} \mathrm{H}_{15} \mathrm{O}_{10}, \mathrm{C}_{10} \mathrm{H}_{16} \mathrm{O}_{10}$ and $\mathrm{C}_{19} \mathrm{H}_{28} \mathrm{O}_{11}$, which represent the majority of the total concentration of HOM. These compounds have also been found to be abundant in the boreal forest when analysing the naturally charged ions (Ehn et al., 2012). The rest of the compounds taken into account in the concentration calculation are listed in Table A1.

During most of the experiments, clear particle formation and growth was observed shortly after the $\alpha$-pinene injection was started. In Fig. 2 the particle size distribution and precursor vapour concentrations during an example ozonolysis experiment are shown. In this experiment the $\alpha$-pinene injection started at noon and the sulfuric acid and HOM concentrations started to increase immediately. The particle growth above $3 \mathrm{~nm}$ can be seen approximately $45 \mathrm{~min}$ after the injection. While the concentration of $\alpha$-pinene continued to increase, the sulfuric acid and HOM concentrations reach their steady-state concentrations after 1 to $2 \mathrm{~h}$. The sulfuric acid reaches its steady-state concentration slightly before the HOM concentration reaches its maximum value, which is expected due to its faster wall loss rate.

The method presented in Sect. 2.3 was used to describe the temporal behaviour of the total HOM concentration. Since 

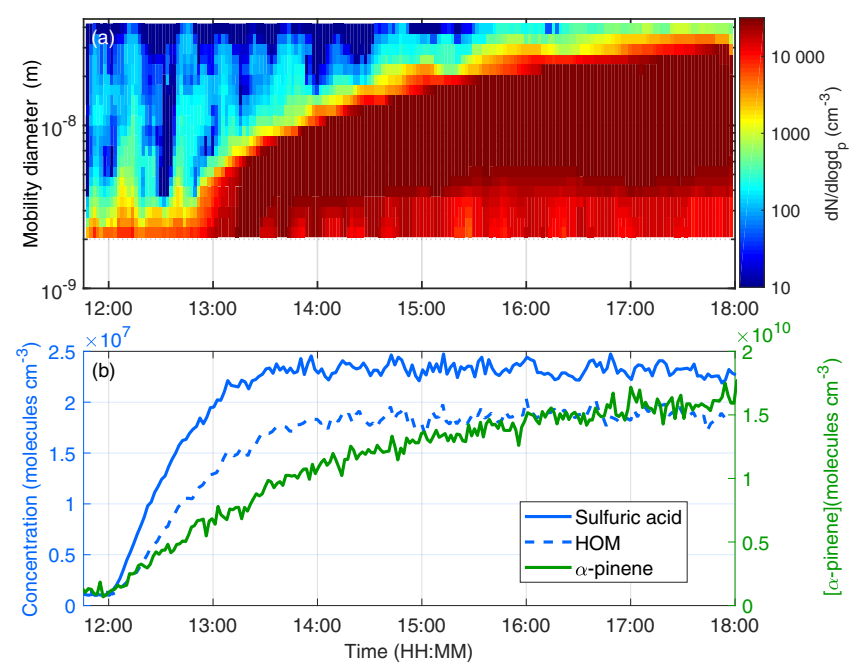

Figure 2. Example of the size distribution (2-40 nm, measured by NAIS) of neutral particles (a) and the concentrations of sulfuric acid, HOM and $\alpha$-pinene (b) during an ozonolysis experiment in the CLOUD chamber.

the total HOM is a sum of several molecules that are formed by the same autoxidation mechanism but possibly via various different intermediate steps, the time evolution of individual HOM molecules can differ from one to another. The time evolution of sulfuric acid and the most abundant HOM was studied in detail using mass spectra integrated over $30 \mathrm{~s}$. The time evolution of the experiment with $600 \mathrm{pptv}$ of $\alpha$-pinene, $22 \mathrm{ppbv}$ of $\mathrm{O}_{3}$ and $67 \mathrm{ppbv}$ of $\mathrm{SO}_{2}$ is shown in Fig. 3. In our studies sulfuric acid concentration started to increase first followed by the concentration of $\mathrm{RO}_{2}\left(\mathrm{C}_{10} \mathrm{H}_{15} \mathrm{O}_{8}\right.$ and $\mathrm{C}_{10} \mathrm{H}_{15} \mathrm{O}_{10}$ ). The formation of closed-shell monomers $\left(\mathrm{C}_{10} \mathrm{H}_{14} \mathrm{O}_{7}\right.$ and $\left.\mathrm{C}_{10} \mathrm{H}_{14} \mathrm{O}_{9}\right)$ started a few minutes after the $\mathrm{RO}_{2}$. The most oxidized closed-shell monomer of the selected HOM $\left(\mathrm{C}_{10} \mathrm{H}_{16} \mathrm{O}_{10}\right)$ and the dimer $\left(\mathrm{C}_{19} \mathrm{H}_{28} \mathrm{O}_{11}\right)$ took more than $10 \mathrm{~min}$ to start increasing. The time evolution of the compounds might give us information about the formation of the molecules. The rapid formation of the radicals and $\mathrm{C}_{10} \mathrm{H}_{15} \mathrm{O}_{8}$ and $\mathrm{C}_{10} \mathrm{H}_{15} \mathrm{O}_{10}$ implies that they are formed via autoxidation in which the peroxy radical undergoes oxidation by adding oxygen molecules stepwise. The selected dimer $\left(\mathrm{C}_{19} \mathrm{H}_{28} \mathrm{O}_{11}\right)$ formation clearly starts later, which supports the hypothesis that it forms from reaction of two $\mathrm{RO}_{2}$ radicals (Ehn et al., 2014; Jokinen et al., 2014). The carbon number 19 can be explained by the loss of $\mathrm{CO}$ from $\mathrm{RO}_{2}$ (Jagiella et al., 2000; Rissanen et al., 2014), followed by reaction with a 10-carbon $\mathrm{RO}_{2}$. The interesting feature in these data is that $\mathrm{C}_{10} \mathrm{H}_{16} \mathrm{O}_{10}$ appears significantly later than most monomers, at the same time that the first dimer appears in the spectrum. This might indicate that this more highly oxidized product is also formed via bimolecular reaction of two $\mathrm{RO}_{2}$ radicals. The time evolution was similar in all the experiments. In the experiments with low $\alpha$-pinene ( $80 \mathrm{pptv})$, the

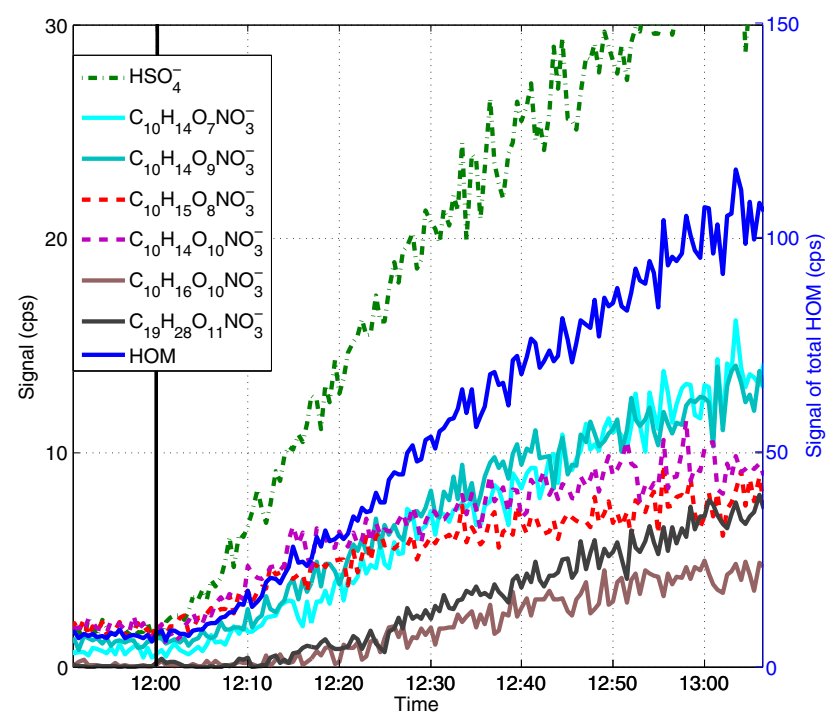

Figure 3. The time evolution of a bisulfate ion (green dotted line), total HOM (blue line) and the HOM signals of the highest concentrations with $30 \mathrm{~s}$ time resolution in an experiment with $600 \mathrm{ppt}$ of $\alpha$-pinene and $67 \mathrm{ppb}$ of $\mathrm{SO}_{2} . \mathrm{RO}_{2}$ signals are shown with dashed lines. All HOMs are detected as clusters with nitrate ions. The black line shows the start of the experiment (i.e. $\alpha$-pinene injection).

concentrations of $\mathrm{C}_{19} \mathrm{H}_{28} \mathrm{O}_{11}$ and $\mathrm{C}_{10} \mathrm{H}_{16} \mathrm{O}_{10}$ were very low. It is also a possibility that the formation of dimers (and other compounds that appear later in the measurements) starts earlier but the concentrations are just below the detection limit. Understanding the exact formation mechanisms of individual HOM compounds requires additional experiments and will be a topic of further studies.

In our experiments, we used $\mathrm{H}_{2}$ to scavenge the $\mathrm{OH}$. In the reaction of $\mathrm{OH}$ and $\mathrm{H}_{2}$, water and $\mathrm{H}$ are produced and subsequently $\mathrm{H}$ can react with $\mathrm{O}_{2}$ to form $\mathrm{HO}_{2}$ (Reactions R1 and $\mathrm{R} 2$ ). $\mathrm{HO}_{2}$ can then react with $\mathrm{RO}_{2}$, ending its autoxidation process (Ehn et al., 2014). This means that in the presence of $\mathrm{HO}_{2}$ the $\mathrm{HOM}$ concentration can be lower because the organic compounds that react with $\mathrm{HO}_{2}$ are not oxidized further into highly oxidized products. In these experiments, we did not have an instrument capable of measuring less oxidized products from $\alpha$-pinene ozonolysis. The relevance of these experiments to the atmosphere depends on the relative and absolute levels of all species participating in the autoxidation process, including $\mathrm{RO}_{2}, \mathrm{HO}_{2}$ and $\mathrm{NO}$ in both the experiment and the atmosphere. Jokinen et al. (2015) also used $\mathrm{H}_{2}$ to scavenge $\mathrm{OH}$, while Ehn et al. (2014) used $\mathrm{CO}$, both of which also produce $\mathrm{H}$ and then $\mathrm{HO}_{2}$ (Reaction R3). Thus, these experiments and the yield terms determined from them are equally affected by $\mathrm{HO}_{2}$. However, Jokinen et al. (2015) also did experiments with propane as an $\mathrm{OH}$ scavenger, which does not produce $\mathrm{HO}_{2}$, and found similar yields as with $\mathrm{H}_{2}$. This implies that $\mathrm{HO}_{2}$ produced by the scavenger reactions does not significantly affect HOM 

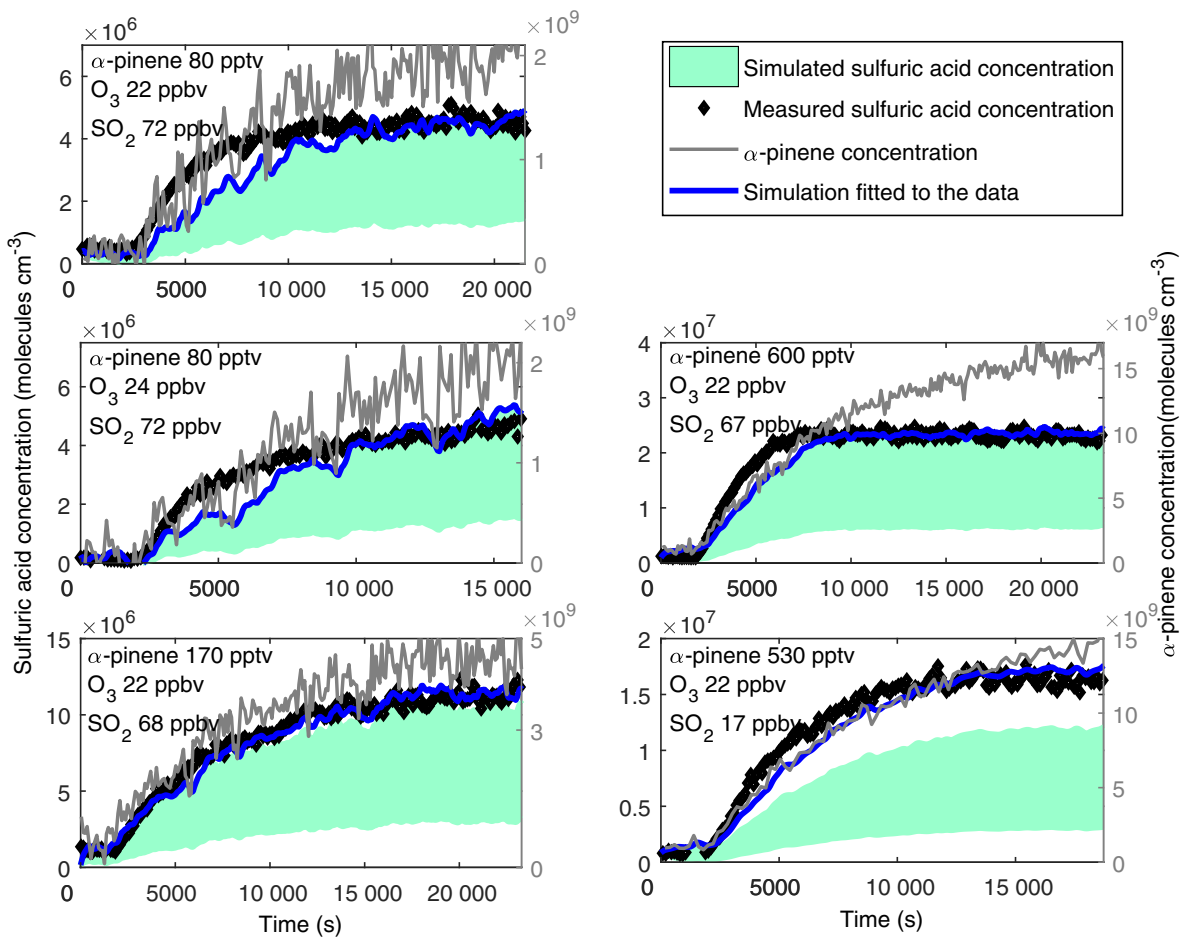

Figure 4. Measured (black dots) and modelled (green shows the concentration with uncertainty) sulfuric acid concentrations formed from the oxidation of $\mathrm{SO}_{2}$ by $\mathrm{sCI}$ in the CLOUD chamber. The simulation with fitted yield term to the measured concentration is shown as a blue line and the $\alpha$-pinene concentration is a grey line. Under conditions of atmospheric concentrations of $\left.\mathrm{OH}_{\left(1 \times 10^{6}\right.} \mathrm{molecules}^{-3}\right)$ the sulfuric acid concentrations would be significantly higher, around $6.3 \times 10^{8}$ molecules $\mathrm{cm}^{-3}$ in the experiment with $67 \mathrm{ppb}$ of $\mathrm{SO}_{2}$ and $1.6 \times 10^{8}$ molecules $\mathrm{cm}^{-3}$ in the experiment with $17 \mathrm{ppb}$ of $\mathrm{SO}_{2}$.

formation.

$$
\begin{aligned}
& \mathrm{OH}+\mathrm{H}_{2} \rightarrow \mathrm{H}_{2} \mathrm{O}+\mathrm{H} \\
& \mathrm{H}+\mathrm{O}_{2} \rightarrow \mathrm{HO}_{2} \\
& \mathrm{OH}+\mathrm{CO} \rightarrow \mathrm{CO}_{2}+\mathrm{H}
\end{aligned}
$$

\subsection{The formation of sulfuric acid}

The sulfuric acid formation in the CLOUD chamber was simulated as described in Sect. 2.3. The measured steady-state concentrations varied between $4 \times 10^{6}$ and $2 \times$ $10^{7}$ molecules $\mathrm{cm}^{-3}$ (Fig. 4). Sulfuric acid concentrations were the highest in the experiments for which the $\alpha$-pinene mixing ratio was also the highest at around $600 \mathrm{pptv}$. The steady-state concentration was reached in $2 \mathrm{~h}$ in the experiment at high $\mathrm{SO}_{2}$ concentrations $(\sim 70 \mathrm{ppbv})$, whereas in the experiment with the same amount of $\alpha$-pinene but significantly lower sulfur dioxide concentration (17 ppbv), the steady state was reached $1 \mathrm{~h}$ later. In the other three experiments the $\alpha$-pinene mixing ratio was clearly lower (80 and $170 \mathrm{pptv}$ ) and the increase in sulfuric acid concentration took more time and continued throughout the whole experiment.
In the simulations, the minimum and maximum concentrations were calculated from the upper and lower limits of the given $k_{\text {loss }} / k_{\mathrm{SCI}}+\mathrm{SO}_{2}$ and sCI yield term in Sipilä et al. (2014). In the CLOUD experiments, the measured sulfuric acid concentrations were at the upper range of the simulated concentrations in all the cases (Fig. 4). In the experiment in which we had the least sulfur dioxide in the chamber, the measured concentration was slightly higher than the simulated one (measured $1.6 \times 10^{7}$ molecules $\mathrm{cm}^{-3}$, upper range simulated concentration $1.2 \times 10^{7}$ molecules $\mathrm{cm}^{-3}$ ). The sulfuric acid was formed in the fast reaction between $\mathrm{SO}_{2}$ and $\mathrm{sCI}$, and thus the formation of sulfuric acid was strongly dependent on the formation of sCI. We calculated yield terms for the $\mathrm{SCI}$ in CLOUD experiments by fitting the model to the measured concentrations. When using a value of $1.6 \times 10^{12}$ for the term $k_{\text {loss }} / k_{\mathrm{SCI}}+\mathrm{SO}_{2}$ (lower end of the range given in Sipilä et al., 2014), the calculated yields of sCI were 22-24\% for the experiments with a higher concentration of $\mathrm{SO}_{2}$ and $32 \%$ for the experiment with low $\mathrm{SO}_{2}$ (Table 2). The higher yield in the experiment with a low $\mathrm{SO}_{2}$ concentration is still within the experimental uncertainties. In the study done in the TROPOS-LFT the sCI yield from $\alpha$-pinene oxidation was determined to be 8-22\% (Sipilä et al., 2014). The simulated sulfuric acid concentration represents the measured concen- 
trations well. When the $\alpha$-pinene concentration was low, the measured $\alpha$-pinene concentration was fluctuating, which led to fluctuation in the simulated sulfuric acid concentration. In the experiment with a middle-range $\alpha$-pinene concentration (170 pptv), the upper bound of the simulated time evolution perfectly matched the measured concentrations so that the trend in the measured and simulated concentration was identical and the difference of the simulated concentration from the measured concentration did not exceed $30 \%$. In the other experiments the measured sulfuric acid concentration increased faster than the simulated concentration in the beginning but then stabilized at the upper level of the simulated concentrations. The difference is still small and mostly within the measurement uncertainty. In all the experiments, the simulated sulfuric acid concentration followed the measured concentration very well after $10000 \mathrm{~s}$ (166 min) and thus the discrepancy cannot be explained by only one term. The simulation can be modified to match the measurements better if, for example, both the sCI yield term and condensation sink values are increased significantly (twofold increase in both condensation sink and sCI yield). However, it seems unlikely that the condensation sink for sulfuric acid would have such a large error. As mentioned earlier, the influence of temperature on the $\mathrm{H}_{2} \mathrm{SO}_{4}$ formation from the gas-phase reaction of monoterpene-derived sCIs has not been investigated. It is likely that we underestimate the sulfuric acid concentration in the CLOUD experiments as we are using the loss term derived from experiments performed at higher temperature.

To compare the sCI oxidation with ambient sulfuric acid formation, we calculated the sulfuric acid produced at a typical ambient $\mathrm{OH}$ concentration for otherwise similar conditions as in these experiments. The sulfur dioxide concentration was high in most of the experiments and with an atmospherically relevant concentration of $\mathrm{OH}(1 \times$ $10^{6}$ molecules $\mathrm{cm}^{-3}$ ) the sulfuric acid concentration would be around $6.3 \times 10^{8}$ molecules $\mathrm{cm}^{-3}\left(\mathrm{SO}_{2} 67 \mathrm{ppbv}\right.$, reaction rate constant $8.5 \times 10^{-13} \mathrm{~cm}^{3} \mathrm{~s}^{-1}$; Weber et al., 1996). With a lower $\mathrm{SO}_{2}$ concentration (17 ppbv) the $\mathrm{OH}$-produced sulfuric acid would be around $1.6 \times 10^{8}$ molecules $\mathrm{cm}^{-3}$. Thus, the sulfuric acid concentrations that resulted from sCI oxidation in these experiments were around $3 \%$ of what would be formed from $\mathrm{OH}$ oxidation in high $\mathrm{SO}_{2}$ conditions and $10 \%$ in low $\mathrm{SO}_{2}$ conditions at typical $\mathrm{OH}$ concentrations. It should be noted that in the atmosphere the mixture of gases is much more complex. In ambient conditions the $\alpha$-pinene concentration is often less than the concentration used in this calculation (600 pptv), but on the other hand, in the atmosphere there are also alkenes other than $\alpha$-pinene that can be oxidized to form sCI. Also the sulfur dioxide concentrations used in the experiments are relatively high for most of the atmosphere, such as rural areas (Mikkonen et al., 2011).

To get more insight into the sulfuric acid production with ambient concentrations we calculated the $24 \mathrm{~h}$ production of sulfuric acid from $\mathrm{OH}$ and $\mathrm{sCI}$ oxidation pathways. We
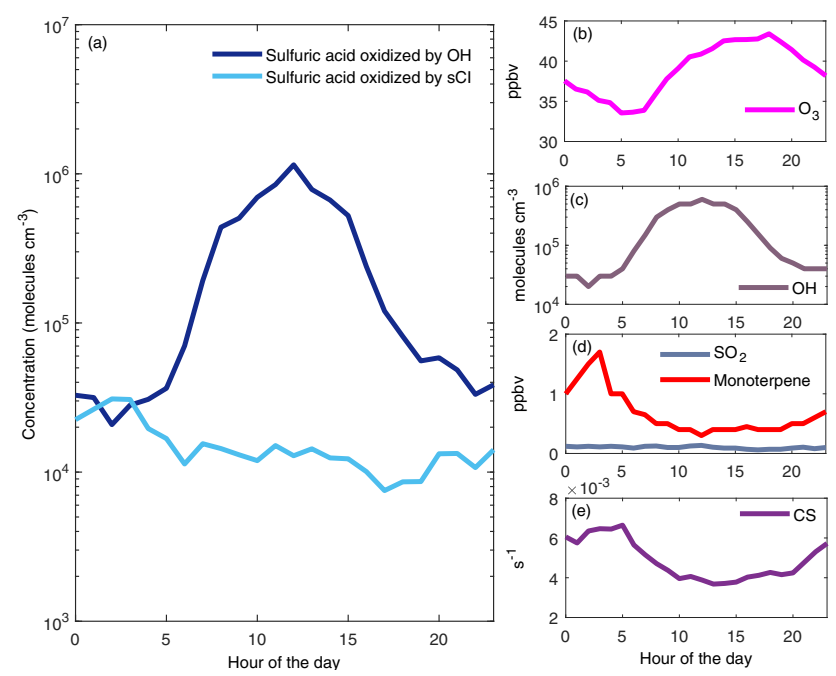

Figure 5. Example of sulfuric acid concentration produced by $\mathrm{OH}$ and $\mathrm{sCI}$ in ambient boreal forest conditions (a). The precursor gas concentrations and condensation sink used are shown in plots (b-e).

used typical spring and summertime concentrations of precursors in boreal forest: measured $\mathrm{OH}$ concentrations (medians of event day concentrations from late March to early June; Petäjä et al., 2009), measured $\mathrm{O}_{3}, \mathrm{SO}_{2}$, (medians of concentrations from April to June in 2013; Smart-SMEAR: https://avaa.tdata.fi/web/smart/smear; Junninen et al., 2009), measured monoterpene concentrations (concentrations measured in July 2004; Rinne et al., 2005) and calculated condensation sink values (median of data from April to June 2013; Junninen et al., 2009; Kulmala et al., 2001). The $24 \mathrm{~h}$ sulfuric acid productions were calculated with an sCI yield of $22 \%$ and the results are shown in Fig. 5a. During the daytime the sulfuric acid produced by $\mathrm{OH}$ dominates but during nighttime both of the production pathways are important. In this example with conditions of boreal forest the $\mathrm{SO}_{2}$ concentration is significantly lower than in our experiments (Fig. 5d; around $0.1 \mathrm{ppb}$ ). Ozone concentrations are lowest during early morning at around $35 \mathrm{ppbv}$, while the concentrations reach 43 ppbv in the evening. The importance of sCI in sulfuric acid production strongly depends on the monoterpene concentrations. In this example the monoterpene concentration is highest during early hours and at that time the sulfuric acid concentration reaches $4 \times 10^{4}$ molecules $\mathrm{cm}^{-3}$. We calculated an sCI yield of $32 \%$ in our experiment with low $\mathrm{SO}_{2}$ and if we use that yield term in the calculation the highest sulfuric acid concentration becomes $6 \times 10^{4}$ molecules $\mathrm{cm}^{-3}$.

\subsection{The formation of $\mathrm{HOM}$}

The HOM formation in the CLOUD chamber was simulated as described in Sect. 2.3. The measured steady-state concentrations of HOM varied between $2 \times 10^{6}$ and $2 \times$ $10^{7}$ molecules $\mathrm{cm}^{-3}$ (Fig. 6). The respective $\alpha$-pinene and 

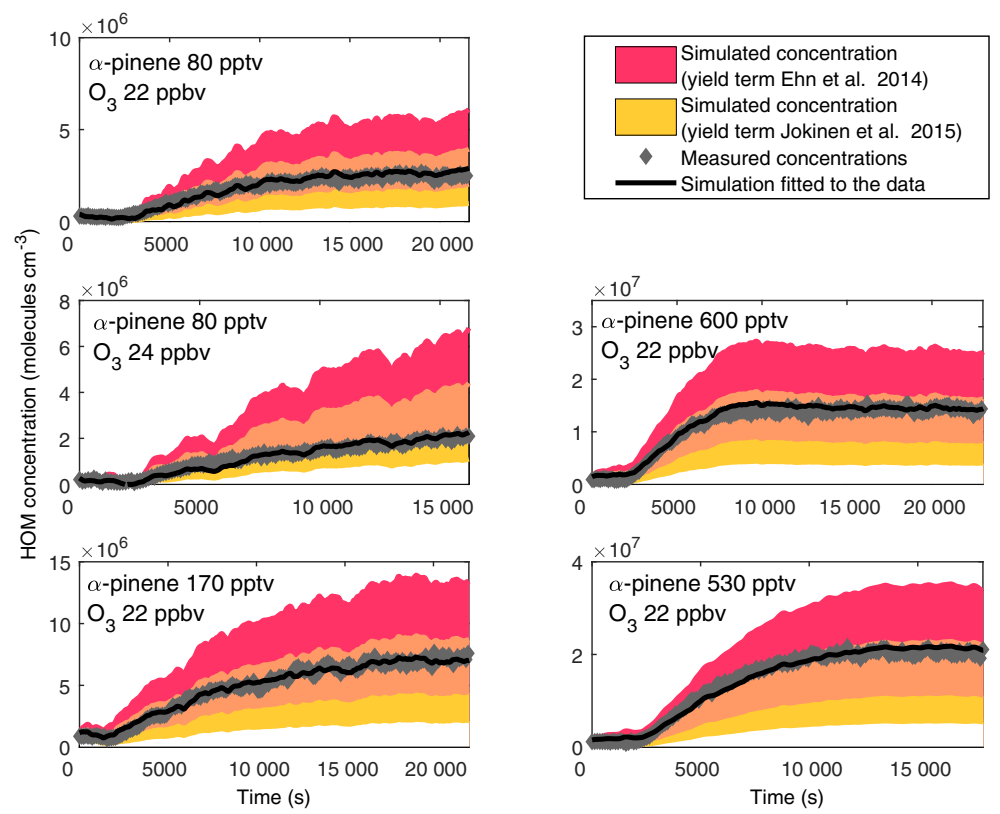

Figure 6. Measured (grey dots) and simulated (shaded area shows the concentration with uncertainty) HOM concentrations formed from the ozonolysis of $\alpha$-pinene in the CLOUD chamber. The simulation with fitted yield term to the measured concentration is shown as a black line. The modelled concentration with a yield term from Ehn et al. (2014) is shown in red, while the concentration with the yield term from Jokinen et al. (2015) is shown in yellow. The overlapping area within the error estimates of these studies is coloured in orange.

ozone concentrations were atmospherically relevant, so these HOM concentrations are similar to those found in ambient air (Sarnela et al., 2015; Yan et al., 2016). We calculated the HOM yield by fitting the model to the measured concentrations and obtained yields of $3.5-6.5 \%$ for the experiments in the CLOUD chamber (Table 2). In previous studies of $\alpha$-pinene ozonolysis, yield terms for HOM formation have been experimentally determined. Ehn et al. (2014) measured a yield of $7 \pm 3.5 \%$ and Jokinen et al. (2015) a yield of $3.4 \%$ with an estimated uncertainty of $-50 \%$ to +100 . Kirkby et al. (2016) made a fit to both neutral and charged experiments and obtained a yield of $2.9 \%$ for the CLOUD experiments. The yields calculated in this study are in good agreement with all previous studies and the simulated time evolution reproduces the measured concentrations very well. The highest difference between the simulated and measured concentration was $40 \%$, but in most experiments the simulated and measured concentrations matched within a $20 \%$ difference.

\section{Conclusions}

In this study we conducted several $\alpha$-pinene ozonolysis experiments in an ultraclean environment, the CLOUD chamber. These experiments were designed to be OH-radical free, thus allowing us to study the formation of highly oxygenated molecules (HOMs) from the ozonolysis of $\alpha$-pinene. The other objective of this study was to observe the formation of sulfuric acid from the oxidation of $\mathrm{SO}_{2}$ by stabilized Criegee intermediates. Both HOM and sulfuric acid concentrations were experimentally measured with a high-resolution timeof-flight mass spectrometer by utilizing a highly selective chemical ionization method. To estimate the molar yield of the HOM and the sCI yield in our experiments, we used a 0-dimensional model with reaction parameters, some of which were obtained from other recent publications on sCI and HOM formation (Ehn et al., 2014; Jokinen et al., 2015; Sipilä et al., 2014).

The formation of HOM was initiated immediately after an $\alpha$-pinene injection into the chamber with a stable ozone concentration. We observed a consecutive formation of peroxy radicals, HOM monomers and dimer species, which is in agreement with previous studies conducted in both a laminar flow tube and in a continuously stirred flow reactor (Ehn et al., 2014; Jokinen et al., 2014). The simulated time evolution of the HOM followed the measured concentrations very precisely and the calculated yields from several experiments were in the range of $3.5-6.5 \%$. The yields observed in the CLOUD chamber were within the range of previously published HOM yields for $\alpha$-pinene ozonolysis (3.5-10.5\% by Ehn et al., 2014, 1.7-6.8 \% by Jokinen et al., 2015, 1.2-5.8\% by Kirkby et al., 2016).

Sulfuric acid in the chamber was assumed to be solely produced via stabilized Criegee intermediates reacting with the added $\mathrm{SO}_{2}$. The formation of sulfuric acid started promptly after the $\alpha$-pinene injection and the associated sCI formation. The measured concentration increased quickly, in some 
experiments even faster than was expected from the simulations. With a high $\mathrm{SO}_{2}$ concentration $(70 \mathrm{ppbv})$, the sCI yields were measured to reach $22-24 \%$, which are on the upper edge of the values found by Sipilä et al. (2014), i.e. $15 \pm 7 \%$. When the $\mathrm{SO}_{2}$ concentration was considerably lower (17 ppbv) the sCI yield was higher (32\%). These results do not deny that $\mathrm{OH}$ is the main daytime oxidizer of sulfur dioxide. In the presence of $\mathrm{OH}$ the role of $\mathrm{sCI}$ in the formation of sulfuric acid is relatively small but in dark conditions there can be considerable sulfuric acid formation due to $\mathrm{SCI}$. The results of this study emphasize the potential importance of stabilized Criegee intermediates in sulfuric acid formation, also in the presence of water vapour. In this paper we introduce a way to simulate the ozonolysis products of $\alpha$-pinene in a simple manner. The results indicate that the CLOUD experiments on $\alpha$-pinene ozonolysis support the recently published chemistry of $\mathrm{HOM}$ and $\mathrm{sCI}$ formation, thus making the experimentally determined yield and loss terms more reliable for modelling and theoretical use.

Data availability. Data that has been used to create the tables and figures presented can be downloaded from Zenodo at https://doi.org/10.5281/zenodo.1170108 (Sarnela et al., 2018). 


\section{Appendix A}

Table A1. The elemental compositions and exact masses of the most abundant isotopes of the HOM compounds that were added together to make the total HOM.

\begin{tabular}{|c|c|}
\hline Elemental composition & Exact mass (Th) \\
\hline $\mathrm{C}_{7} \mathrm{H}_{10} \mathrm{O}_{4} \mathrm{NO}_{3}^{-}$ & 220.0463 \\
\hline $\mathrm{C}_{5} \mathrm{H}_{6} \mathrm{O}_{6} \mathrm{NO}_{3}^{-}$ & 224.0048 \\
\hline $\mathrm{C}_{5} \mathrm{H}_{6} \mathrm{O}_{7} \mathrm{NO}_{3}^{-}$ & 239.9997 \\
\hline $\mathrm{C}_{8} \mathrm{H}_{12} \mathrm{O}_{7} \mathrm{NO}_{3}^{-}$ & 282.0461 \\
\hline $\mathrm{C}_{8} \mathrm{H}_{12} \mathrm{O}_{8} \mathrm{NO}_{3}^{-}$ & 298.0416 \\
\hline $\mathrm{C}_{10} \mathrm{H}_{14} \mathrm{O}_{7} \mathrm{NO}_{3}^{-}$ & 308.0623 \\
\hline $\mathrm{C}_{9} \mathrm{H}_{12} \mathrm{O}_{8} \mathrm{NO}_{3}^{-}$ & 310.0416 \\
\hline $\mathrm{C}_{10} \mathrm{H}_{16} \mathrm{O}_{7} \mathrm{NO}_{3}^{-}$ & 310.0780 \\
\hline $\mathrm{C}_{8} \mathrm{H}_{12} \mathrm{O}_{9} \mathrm{NO}_{3}^{-}$ & 314.0365 \\
\hline $\mathrm{C}_{10} \mathrm{H}_{14} \mathrm{O}_{8} \mathrm{NO}_{3}^{-}$ & 324.0572 \\
\hline $\mathrm{C}_{10} \mathrm{H}_{15} \mathrm{O}_{8} \mathrm{NO}_{3}^{-}$ & 325.0651 \\
\hline $\mathrm{C}_{9} \mathrm{H}_{12} \mathrm{O}_{9} \mathrm{NO}_{3}^{-}$ & 326.0365 \\
\hline $\mathrm{C}_{10} \mathrm{H}_{16} \mathrm{O}_{8} \mathrm{NO}_{3}^{-}$ & 326.0729 \\
\hline $\mathrm{C}_{9} \mathrm{H}_{14} \mathrm{O}_{9} \mathrm{NO}_{3}^{-}$ & 328.0521 \\
\hline $\mathrm{C}_{10} \mathrm{H}_{14} \mathrm{O}_{9} \mathrm{NO}_{3}^{-}$ & 340.0521 \\
\hline $\mathrm{C}_{9} \mathrm{H}_{12} \mathrm{O}_{10} \mathrm{NO}_{3}^{-}$ & 342.0314 \\
\hline $\mathrm{C}_{10} \mathrm{H}_{16} \mathrm{O}_{9} \mathrm{NO}_{3}^{-}$ & 342.0678 \\
\hline $\mathrm{C}_{10} \mathrm{H}_{14} \mathrm{O}_{10} \mathrm{NO}_{3}^{-}$ & 356.0471 \\
\hline $\mathrm{C}_{10} \mathrm{H}_{15} \mathrm{O}_{10} \mathrm{NO}_{3}^{-}$ & 357.0549 \\
\hline $\mathrm{C}_{9} \mathrm{H}_{12} \mathrm{O}_{11} \mathrm{NO}_{3}^{-}$ & 358.0263 \\
\hline $\mathrm{C}_{10} \mathrm{H}_{16} \mathrm{O}_{10} \mathrm{NO}_{3}^{-}$ & 358.0627 \\
\hline $\mathrm{C}_{10} \mathrm{H}_{14} \mathrm{O}_{11} \mathrm{NO}_{3}^{-}$ & 372.0420 \\
\hline $\mathrm{C}_{9} \mathrm{H}_{12} \mathrm{O}_{12} \mathrm{NO}_{3}^{-}$ & 374.0212 \\
\hline $\mathrm{C}_{10} \mathrm{H}_{16} \mathrm{O}_{11} \mathrm{NO}_{3}^{-}$ & 374.0576 \\
\hline $\mathrm{C}_{10} \mathrm{H}_{14} \mathrm{O}_{13} \mathrm{NO}_{3}^{-}$ & 404.0318 \\
\hline $\mathrm{C}_{15} \mathrm{H}_{28} \mathrm{O}_{12} \mathrm{NO}_{3}^{-}$ & 462.1464 \\
\hline $\mathrm{C}_{17} \mathrm{H}_{24} \mathrm{O}_{11} \mathrm{NO}_{3}^{-}$ & 466.1202 \\
\hline $\mathrm{C}_{17} \mathrm{H}_{26} \mathrm{O}_{11} \mathrm{NO}_{3}^{-}$ & 468.1359 \\
\hline $\mathrm{C}_{18} \mathrm{H}_{26} \mathrm{O}_{11} \mathrm{NO}_{3}^{-}$ & 480.1359 \\
\hline $\mathrm{C}_{14} \mathrm{H}_{20} \mathrm{O}_{15} \mathrm{NO}_{3}^{-}$ & 490.0686 \\
\hline $\mathrm{C}_{19} \mathrm{H}_{28} \mathrm{O}_{11} \mathrm{NO}_{3}^{-}$ & 494.1515 \\
\hline $\mathrm{C}_{20} \mathrm{H}_{32} \mathrm{O}_{11} \mathrm{NO}_{3}^{-}$ & 510.1828 \\
\hline $\mathrm{C}_{17} \mathrm{H}_{26} \mathrm{O}_{14} \mathrm{NO}_{3}^{-}$ & 516.1206 \\
\hline $\mathrm{C}_{20} \mathrm{H}_{30} \mathrm{O}_{12} \mathrm{NO}_{3}^{-}$ & 524.1621 \\
\hline $\mathrm{C}_{19} \mathrm{H}_{28} \mathrm{O}_{13} \mathrm{NO}_{3}^{-}$ & 526.1414 \\
\hline $\mathrm{C}_{18} \mathrm{H}_{26} \mathrm{O}_{14} \mathrm{NO}_{3}^{-}$ & 528.1206 \\
\hline $\mathrm{C}_{18} \mathrm{H}_{28} \mathrm{O}_{14} \mathrm{NO}_{3}^{-}$ & 530.1363 \\
\hline $\mathrm{C}_{17} \mathrm{H}_{26} \mathrm{O}_{15} \mathrm{NO}_{3}^{-}$ & 532.1155 \\
\hline $\mathrm{C}_{20} \mathrm{H}_{30} \mathrm{O}_{13} \mathrm{NO}_{3}^{-}$ & 540.1570 \\
\hline $\mathrm{C}_{20} \mathrm{H}_{32} \mathrm{O}_{13} \mathrm{NO}_{3}^{-}$ & 542.1727 \\
\hline $\mathrm{C}_{17} \mathrm{H}_{26} \mathrm{O}_{16} \mathrm{NO}_{3}^{-}$ & 548.1105 \\
\hline $\mathrm{C}_{20} \mathrm{H}_{30} \mathrm{O}_{14} \mathrm{NO}_{3}^{-}$ & 556.1519 \\
\hline $\mathrm{C}_{18} \mathrm{H}_{28} \mathrm{O}_{16} \mathrm{NO}_{3}^{-}$ & 562.1261 \\
\hline $\mathrm{C}_{20} \mathrm{H}_{30} \mathrm{O}_{15} \mathrm{NO}_{3}^{-}$ & 572.1468 \\
\hline $\mathrm{C}_{20} \mathrm{H}_{32} \mathrm{O}_{15} \mathrm{NO}_{3}^{-}$ & 574.1625 \\
\hline $\mathrm{C}_{20} \mathrm{H}_{30} \mathrm{O}_{16} \mathrm{NO}_{3}^{-}$ & 588.1418 \\
\hline $\mathrm{C}_{18} \mathrm{H}_{28} \mathrm{O}_{18} \mathrm{NO}_{3}^{-}$ & 594.1159 \\
\hline $\mathrm{C}_{20} \mathrm{H}_{30} \mathrm{O}_{18} \mathrm{NO}_{3}^{-}$ & 620.1316 \\
\hline
\end{tabular}


Competing interests. The authors declare that they have no conflict of interest.

Acknowledgements. We would like to thank CERN for supporting CLOUD with technical and financial resources. We also thank Theo Kurtén for valuable input on ion molecule collision frequencies. This research has received funding from the EC Seventh Framework Programme (Marie Curie Initial Training Network CLOUD-ITN no. 215072, MC-ITN CLOUD-TRAIN no. 316662, ERC-StG-ATMOGAIN no. 278277, ERC-Advanced ATMNUCLE grant no. 227463, ERC-StG-GASPARCON no. 714621 and ERC-StG-COALA no. 638703), the German Federal Ministry of Education and Research (project nos. 01LK0902A and 01LK1222A), the Swiss National Science Foundation (project nos. 200020_135307, 200020_152907, 20FI20_149002, 200021_140663 and and grant P2EZP2_168787), the Academy of Finland Center of Excellence programme (grant no. 307331), the Academy of Finland (CoE project no. 1118615, LASTU project no. 135054; 296628 and 299574), the Nessling Foundation, the Austrian Science Fund (FWF; project no. J3198-N21), the EU's Horizon 2020 research and innovation programme under the Marie Sklodowska-Curie (no. 656994), the Swedish Research Council, Vetenskapsrådet (grant no. 2011-5120), the Portuguese Foundation for Science and Technology (project no. CERN/FP/116387/2010), the Presidium of the Russian Academy of Sciences and the Russian Foundation for Basic Research (grants 08-02-91006CERN and 12-02-91522-CERN), Dreyfus Award EP-11-117, the Davidow Foundation, the US National Science Foundation (grants AGS1136479, AGS1447056, AGS1439551 and CHE1012293), the US Department of Energy (grant DE-SC00014469) and the FP7 project BACCHUS (grant agreement 603445).

Edited by: Frank Keutsch

Reviewed by: two anonymous referees

\section{References}

Almeida, J., Schobesberger, S., Kürten, A., Ortega, I. K., Kupiainen-Määttä, O., Praplan, A. P., Adamov, A., Amorim, A., Bianchi, F., Breitenlechner, M., David, A., Dommen, J., Donahue, N. M., Downard, A., Dunne, E., Duplissy, J., Ehrhart, S., Flagan, R. C., Franchin, A., Guida, R., Hakala, J., Hansel, A., Heinritzi, M., Henschel, H., Jokinen, T., Junninen, H., Kajos, M., Kangasluoma, J., Keskinen, H., Kupc, A., Kurtén, T., Kvashin, A. N., Laaksonen, A., Lehtipalo, K., Leiminger, M., Leppä, J., Loukonen, V., Makhmutov, V., Mathot, S., McGrath, M. J., Nieminen, T., Olenius, T., Onnela, A., Petäjä, T., Riccobono, F., Riipinen, I., Rissanen, M., Rondo, L., Ruuskanen, T., Santos, F. D., Sarnela, N., Schallhart, S., Schnitzhofer, R., Seinfeld, J. H., Simon, M., Sipilä, M., Stozhkov, Y., Stratmann, F., Tomé, A., Tröstl, J., Tsagkogeorgas, G., Vaattovaara, P., Viisanen, Y., Virtanen, A., Vrtala, A., Wagner, P. E., Weingartner, E., Wex, H., Williamson, C., Wimmer, D., Ye, P., Yli-Juuti, T., Carslaw, K. S., Kulmala, M., Curtius, J., Baltensperger, U., Worsnop, D. R., Vehkamäki, H., and Kirkby, J.: Molecular understanding of sulphuric acid-amine particle nucleation in the atmosphere, Nature, 502, 359-363, https://doi.org/10.1038/nature12663, 2013.
Atkinson, R., Baulch, D. L., Cox, R. A., Crowley, J. N., Hampson, R. F., Hynes, R. G., Jenkin, M. E., Rossi, M. J., Troe, J., and IUPAC Subcommittee: Evaluated kinetic and photochemical data for atmospheric chemistry: Volume II - gas phase reactions of organic species, Atmos. Chem. Phys., 6, 3625-4055, https://doi.org/10.5194/acp-6-3625-2006, 2006.

Ball, S. M., Hanson, D. R., Eisele, F. L., and McMurry, P. H.: Laboratory studies of particle nucleation: Initial results for $\mathrm{H}_{2} \mathrm{SO}_{4}$, $\mathrm{H}_{2} \mathrm{O}$, and $\mathrm{NH}_{3}$ vapors, J. Geophys. Res., 104, 23709-23718, https://doi.org/10.1029/1999JD900411, 1999.

Berndt, T., Böge, O., Stratmann, F., Heintzenberg, J., and Kulmala, M.: Rapid formation of sulfuric acid particles at near-atmospheric conditions, Science, 307, 698-700, https://doi.org/10.1126/science.1104054, 2005.

Berndt, T., Stratmann, F., Sipilä, M., Vanhanen, J., Petäjä, T., Mikkilä, J., Grüner, A., Spindler, G., Lee Mauldin III, R., Curtius, J., Kulmala, M., and Heintzenberg, J.: Laboratory study on new particle formation from the reaction $\mathrm{OH}+\mathrm{SO}_{2}$ : influence of experimental conditions, $\mathrm{H}_{2} \mathrm{O}$ vapour, $\mathrm{NH}_{3}$ and the amine tert-butylamine on the overall process, Atmos. Chem. Phys., 10, 7101-7116, https://doi.org/10.5194/acp-10-7101-2010, 2010.

Berndt, T., Jokinen, T., Mauldin, R. L., Petäjä, T., Herrmann, H., Junninen, H., Paasonen, P., Worsnop, D. R., and Sipilä, M.: Gas-phase ozonolysis of selected olefins: The yield of stabilized criegee intermediate and the reactivity toward $\mathrm{SO}_{2}$, J. Phys. Chem. Lett., 3, 2892-2896, https://doi.org/10.1021/jz301158u, 2012.

Berndt, T., Voigtländer, J., Stratmann, F., Junninen, H., Mauldin, R. L., Sipilä, M., Kulmala, M., and Herrmann, H.: Competing atmospheric reactions of $\mathrm{CH}_{2} \mathrm{OO}$ with $\mathrm{SO}_{2}$ and water vapour, Phys. Chem. Chem. Phys., 16, 19130-19136, https://doi.org/10.1039/C4CP02345E, 2014a.

Berndt, T., Sipilä, M., Stratmann, F., Petäjä, T., Vanhanen, J., Mikkilä, J., Patokoski, J., Taipale, R., Mauldin III, R. L., and Kulmala, M.: Enhancement of atmospheric $\mathrm{H}_{2} \mathrm{SO}_{4} / \mathrm{H}_{2} \mathrm{O}$ nucleation: organic oxidation products versus amines, Atmos. Chem. Phys., 14, 751-764, https://doi.org/10.5194/acp-14-751-2014, 2014 b.

Berndt, T., Jokinen, T., Sipilä, M., Mauldin, R. L., Herrmann, H., Stratmann, F., Junninen, H., and Kulmala, M. $\mathrm{H}_{2} \mathrm{SO}_{4}$ formation from the gas-phase reaction of stabilized Criegee Intermediates with $\mathrm{SO}_{2}$ : Influence of water vapour content and temperature, Atmos. Environ., 89, 603-612, https://doi.org/10.1016/j.atmosenv.2014.02.062, 2014c.

Bianchi, F., Tröstl, J., Junninen, H., Frege, C., Henne, S., Hoyle, C. R., Molteni, U., Herrmann, E., Adamov, A., Bukowiecki, N., Chen, X., Duplissy, J., Gysel, M., Hutterli, M., Kangasluoma, J., Kontkanen, J., Kürten, A., Manninen, H. E., Münch, S., Peräkylä, O., Petäjä, T., Rondo, L., Williamson, C., Weingartner, E., Curtius, J., Worsnop, D. R., Kulmala, M., Dommen, J., and Baltensperger, $\mathrm{U} . \mathrm{N}$ New particle formation in the free troposphere: A question of chemistry and timing, Science, 352, 1109-1112, https://doi.org/10.1126/science.aad5456, 2016.

Boy, M., Mogensen, D., Smolander, S., Zhou, L., Nieminen, T., Paasonen, P., Plass-Dülmer, C., Sipilä, M., Petäjä, T., Mauldin, L., Berresheim, H., and Kulmala, M.: Oxidation of $\mathrm{SO}_{2}$ by stabilized Criegee intermediate ( $\mathrm{SCI}$ ) radicals as a crucial source for atmospheric sulfuric acid concentrations, Atmos. Chem. Phys., 13, 3865-3879, https://doi.org/10.5194/acp-13-3865-2013, 2013. 
Chuong, B., Zhang, J., and Donahue, N. M.: Cycloalkene Ozonolysis: Collisionally Mediated Mechanistic Branching, J. Am. Chem. Soc., 126, 12363-12373, https://doi.org/10.1021/ja0485412, 2004.

Cox, R. A. and Penkett, S. A.: Oxidation of Atmospheric $\mathrm{SO}_{2}$ by Products of the Ozone-Olefin Reaction, Nature, 230, 321-322, https://doi.org/10.1038/230321a0, 1971.

Criegee, R.: Mechanism of Ozonolysis, Angew. Chem. Int. Edit., 14, 745-752, https://doi.org/10.1002/anie.197507451, 1975.

Donahue, N. M., Drozd, G. T., Epstein, S. A., Presto, A. A., and Kroll, J. H.: Adventures in ozoneland: down the rabbit-hole, Phys. Chem. Chem. Phys., 13, 10848-10857, https://doi.org/10.1039/C0CP02564J, 2011.

Donahue, N. M., Kroll, J. H., Pandis, S. N., and Robinson, A. L.: A two-dimensional volatility basis set - Part 2: Diagnostics of organic-aerosol evolution, Atmos. Chem. Phys., 12, 615-634, https://doi.org/10.5194/acp-12-615-2012, 2012.

Drozd, G. T. and Donahue, N. M.: Pressure dependence of stabilized Criegee intermediate formation from a sequence of alkene, J. Phys. Chem. A, 115, 4381-4387, https://doi.org/10.1021/jp2001089, 2011.

Duplissy, J., Merikanto, J., Franchin, A., Tsagkogeorgas, G., Kangasluoma, J., Wimmer, D., Vuollekoski, H., Schobesberger, S., Lehtipalo, K., Flagan, R. C., Brus, D., Donahue, N. M., Vehkamäki, H., Almeida, J., Amorim, A., Barmet, P., Bianchi, F., Breitenlechner, M., Dunne, E. M., Guida, R., Henschel, H., Junninen, H., Kirkby, J., Kürten, A., Kupc, A., Määttänen, A., Makhmutov, V., Mathot, S., Nieminen, T., Onnela, A., Praplan, A. P., Riccobono, F., Rondo, L., Steiner, G., Tome, A., Walther, H., Baltensperger, U., Carslaw, K. S., Dommen, J., Hansel, A., Petäjä, T., Sipilä, M., Stratmann, F., Vrtala, A., Wagner, P. E., Worsnop, D. R., Curtius, J., and Kulmala, M.: Effect of ions on sulfuric acid-water binary particle formation: 2. Experimental data and comparison with QC-normalized classical nucleation theory, J. Geophys. Res.-Atmos., 121, 1752-1775, https://doi.org/10.1002/2015JD023539, 2016.

Ehn, M., Kleist, E., Junninen, H., Petäjä, T., Lönn, G., Schobesberger, S., Dal Maso, M., Trimborn, A., Kulmala, M., Worsnop, D. R., Wahner, A., Wildt, J., and Mentel, Th. F.: Gas phase formation of extremely oxidized pinene reaction products in chamber and ambient air, Atmos. Chem. Phys., 12, 5113-5127, https://doi.org/10.5194/acp-12-5113-2012, 2012.

Ehn, M., Thornton, J. A., Kleist, E., Sipilä, M., Junninen, H., Pullinen, I., Springer, M., Rubach, F., Tillmann, R., Lee, B., Lopez-Hilfiker, F., Andres, S., Acir, I.-H., Rissanen, M., Jokinen, T., Schobesberger, S., Kangasluoma, J., Kontkanen, J., Nieminen, T., Kurtén, T., Nielsen, L. B., Jørgensen, S., Kjaergaard, H. G., Canagaratna, M., Maso, M. D., Berndt, T., Petäjä, T., Wahner, A., Kerminen, V.-M., Kulmala, M., Worsnop, D. R., Wildt, J., and Mentel, T. F.: A large source of lowvolatility secondary organic aerosol, Nature, 506, 476-479, https://doi.org/10.1038/nature13032, 2014.

Eisele, F. L. and Tanner, D. J.: Measurement of the gas phase concentration of $\mathrm{H}_{2} \mathrm{SO}_{4}$ and methane sulfonic acid and estimates of $\mathrm{H}_{2} \mathrm{SO}_{4}$ production and loss in the atmosphere, J. Geophys. Res., 98, 9001-9010, https://doi.org/10.1029/93JD00031, 1993.

Griffin, R. J., Cocker, D. R., Flagan, R. C., and Seinfeld, J. H.: Organic aerosol formation from the oxidation of biogenic hydrocarbons, J. Geophys. Res., 104, 3555-3567, https://doi.org/10.1029/1998JD100049, 1999.

Guenther, A., Hewitt, C. N., Geron, C., Graedel, T., Harley, P., Klinger, L., Lerdau, M., Mckay, W. A., Pierce, T., Scholes, B., Steinbrecher, R., Tallamraju, R., Taylor, J., and Zimmerman, P. A global model of natural volatile organic compound emissions, J. Geophys. Res., 100, 8873-8892, https://doi.org/10.1029/94JD02950, 1995.

Herron, J. T., Martinez, R. I., and Huie, R. E.: Kinetics and energetics of the criegee intermediate in the gas phase. I. The criegee intermediate in ozone-alkene reactions, Int. J. Chem. Kinet., 14, 201-224, https://doi.org/10.1002/kin.550140302, 1982.

Huang, H.-L., Chao, W., and Lin, J. J.-M.: Kinetics of a Criegee intermediate that would survive high humidity and may oxidize atmospheric $\mathrm{SO}_{2}$, P. Natl. Acad. Sci. USA., 112, 10857-10862, https://doi.org/10.1073/pnas.1513149112, 2015.

Hyttinen, N., Kupiainen-Määttä, O., Rissanen, M. P., Muuronen, M., Ehn, M., and Kurtén, T.: Modeling the Charging of Highly Oxidized Cyclohexene Ozonolysis Products Using Nitrate-Based Chemical Ionization, J. Phys. Chem. A, 119, 6339-6345, https://doi.org/10.1021/acs.jpca.5b01818, 2015.

Jagiella, S., Libuda, H. G., and Zabel, F.: Thermal stability of carbonyl radicals Part I. Straight-chain and branched $\mathrm{C}_{4}$ and $\mathrm{C}_{5}$ acyl radicals, Phys. Chem. Chem. Phys., 2, 1175-1181, https://doi.org/10.1039/a909557h, 2000.

Jen, C. N., Hanson, D. R., and McMurry, P. H.: Towards Reconciling Measurements of Atmospherically Relevant Clusters by Chemical Ionization Mass Spectrometry and Mobility Classification/Vapor Condensation, Aerosol Sci. Tech., 49, i-iii, https://doi.org/10.1080/02786826.2014.1002602, 2015.

Johnson, D. and Marston, G.: The gas-phase ozonolysis of unsaturated volatile organic compounds in the troposphere, Chem. Soc. Rev., 37, 699-716, https://doi.org/10.1039/b704260b, 2008.

Jokinen, T., Sipilä, M., Junninen, H., Ehn, M., Lönn, G., Hakala, J., Petäjä, T., Mauldin III, R. L., Kulmala, M., and Worsnop, D. R.: Atmospheric sulphuric acid and neutral cluster measurements using CI-APi-TOF, Atmos. Chem. Phys., 12, 4117-4125, https://doi.org/10.5194/acp-12-4117-2012, 2012.

Jokinen, T., Sipilä, M., Richters, S., Kerminen, V.-M., Paasonen, P., Stratmann, F., Worsnop, D., Kulmala, M., Ehn, M., Herrmann, H., and Berndt, T.: Rapid Autoxidation Forms Highly Oxidized $\mathrm{RO}_{2}$ Radicals in the Atmosphere, Angew. Chem. Int. Edit., 53, 14596-14600, https://doi.org/10.1002/anie.201408566, 2014.

Jokinen, T., Berndt, T., Makkonen, R., Kerminen, V.-M., Junninen, H., Paasonen, P., Stratmann, F., Herrmann, H., Guenther, A. B., Worsnop, D. R., Kulmala, M., Ehn, M., and Sipilä, M.: Production of extremely low volatile organic compounds from biogenic emissions: Measured yields and atmospheric implications, P. Natl. Acad. Sci. USA, 112, 7123-7128, https://doi.org/10.1073/pnas.1423977112, 2015.

Junninen, H., Lauri, A., Keronen, P., Aalto, P., Hiltunen, V., Hari, P., and Kulmala, M.: Smart-SMEAR: On-line data exploration and visualization tool for SMEAR stations, Boreal Environ. Res., 14, 447-457, 2009.

Junninen, H., Ehn, M., Petäjä, T., Luosujärvi, L., Kotiaho, T., Kostiainen, R., Rohner, U., Gonin, M., Fuhrer, K., Kulmala, M., and Worsnop, D. R.: A high-resolution mass spectrometer to measure atmospheric ion composition, Atmos. Meas. Tech., 3, 10391053, https://doi.org/10.5194/amt-3-1039-2010, 2010. 
Kirkby, J., Curtius, J., Almeida, J., Dunne, E., Duplissy, J., Ehrhart, S., Franchin, A., Gagné, S., Ickes, L., Kürten, A., Kupc, A., Metzger, A., Riccobono, F., Rondo, L., Schobesberger, S., Tsagkogeorgas, G., Wimmer, D., Amorim, A., Bianchi, F., Breitenlechner, M., David, A., Dommen, J., Downard, A., Ehn, M., Flagan, R. C., Haider, S., Hansel, A., Hauser, D., Jud, W., Junninen, H., Kreissl, F., Kvashin, A., Laaksonen, A., Lehtipalo, K., Lima, J., Lovejoy, E. R., Makhmutov, V., Mathot, S., Mikkilä, J., Minginette, P., Mogo, S., Nieminen, T., Onnela, A., Pereira, P., Petäjä, T., Schnitzhofer, R., Seinfeld, J. H., Sipilä, M., Stozhkov, Y., Stratmann, F., Tomé, A., Vanhanen, J., Viisanen, Y., Vrtala, A., Wagner, P. E., Walther, H., Weingartner, E., Wex, H., Winkler, P. M., Carslaw, K. S., Worsnop, D. R., Baltensperger, U., and Kulmala, M.: Role of sulphuric acid, ammonia and galactic cosmic rays in atmospheric aerosol nucleation, Nature, 476, 429-433, https://doi.org/10.1038/nature10343, 2011.

Kirkby, J., Duplissy, J., Sengupta, K., Frege, C., Gordon, H., Williamson, C., Heinritzi, M., Simon, M., Yan, C., Almeida, J., Tröstl, J., Nieminen, T., Ortega, I. K., Wagner, R., Adamov, A., Amorim, A., Bernhammer, A.-K., Bianchi, F., Breitenlechner, M., Brilke, S., Chen, X., Craven, J., Dias, A., Ehrhart, S., Flagan, R. C., Franchin, A., Fuchs, C., Guida, R., Hakala, J., Hoyle, C. R., Jokinen, T., Junninen, H., Kangasluoma, J., Kim, J., Krapf, M., Kürten, A., Laaksonen, A., Lehtipalo, K., Makhmutov, V., Mathot, S., Molteni, U., Onnela, A., Peräkylä, O., Piel, F., Petäjä, T., Praplan, A. P., Pringle, K., Rap, A., Richards, N. A. D., Riipinen, I., Rissanen, M. P., Rondo, L., Sarnela, N., Schobesberger, S., Scott, C. E., Seinfeld, J. H., Sipilä, M., Steiner, G., Stozhkov, Y., Stratmann, F., Tomé, A., Virtanen, A., Vogel, A. L., Wagner, A. C., Wagner, P. E., Weingartner, E., Wimmer, D., Winkler, P. M., Ye, P., Zhang, X., Hansel, A., Dommen, J., Donahue, N. M., Worsnop, D. R., Baltensperger, U., Kulmala, M., Carslaw, K. $\mathrm{S}$., and Curtius, J.: Ion-induced nucleation of pure biogenic particles, Nature, 533, 521-526, https://doi.org/10.1038/nature17953, 2016.

Kulmala, M., Dal Maso, M., Mäkelä, J. M., Pirjola, L., Väkevä, M., Aalto, P., Miikkulainen, P., Hämeri, K., and O'Dowd, C. D.: On the formation, growth and composition of nucleation mode particles, Tellus B, 53, 479-490, https://doi.org/10.3402/tellusb.v53i4.16622, 2001.

Kulmala, M., Vehkamäki, H., Petäjä, T., Dal Maso, M., Lauri, A., Kerminen, V.-M., Birmili, W., and McMurry, P. H.: Formation and growth rates of ultrafine atmospheric particles: a review of observations, J. Aerosol Sci., 35, 143-176, https://doi.org/10.1016/j.jaerosci.2003.10.003, 2004.

Kürten, A., Rondo, L., Ehrhart, S., and Curtius, J.: Performance of a corona ion source for measurement of sulfuric acid by chemical ionization mass spectrometry, Atmos. Meas. Tech., 4, 437-443, https://doi.org/10.5194/amt-4-437-2011, 2011.

Kürten, A., Rondo, L., Ehrhart, S., and Curtius, J.: Calibration of a chemical ionization mass spectrometer for the measurement of gaseous sulfuric acid, J. Phys. Chem. A, 116, 6375-6386, https://doi.org/10.1021/jp212123n, 2012.

Kürten, A., Jokinen, T., Simon, M., Sipilä, M., Sarnela, N., Junninen, H., Adamov, A., Almeida, J., Amorim, A., Bianchi, F., Breitenlechner, M., Dommen, J., Donahue, N. M., Duplissy, J., Ehrhart, S., Flagan, R. C., Franchin, A., Hakala, J., Hansel, A., Heinritzi, M., Hutterli, M., Kangasluoma, J., Kirkby, J., Laaksonen, A., Lehtipalo, K., Leiminger, M., Makhmutov, V., Mathot,
S., Onnela, A., Petäjä, T., Praplan, A. P., Riccobono, F., Rissanen, M. P., Rondo, L., Schobesberger, S., Seinfeld, J. H., Steiner, G., Tomé, A., Tröstl, J., Winkler, P. M., Williamson, C., Wimmer, D., Ye, P., Baltensperger, U., Carslaw, K. S., Kulmala, M., Worsnop, D. R., and Curtius, J.: Neutral molecular cluster formation of sulfuric acid-dimethylamine observed in real time under atmospheric conditions, P. Natl. Acad. Sci. USA, 111, 1501915024, https://doi.org/10.1073/pnas.1404853111, 2014.

Kurtén, T., Loukonen, V., Vehkamäki, H., and Kulmala, M.: Amines are likely to enhance neutral and ion-induced sulfuric acid-water nucleation in the atmosphere more effectively than ammonia, Atmos. Chem. Phys., 8, 4095-4103, https://doi.org/10.5194/acp-84095-2008, 2008.

Lindinger, W., Hansel, A., and Jordan, A.: On-line monitoring of volatile organic compounds at pptv levels by means of protontransfer-reaction mass spectrometry (PTR-MS) medical applications, food control and environmental research, Int. J. Mass Spectrom., 173, 191-241, https://doi.org/10.1016/S01681176(97)00281-4, 1998.

Lucas, D. D. and Prinn, R. G.: Parametric sensitivity and uncertainty analysis of dimethylsulfide oxidation in the clear-sky remote marine boundary layer, Atmos. Chem. Phys., 5, 15051525, https://doi.org/10.5194/acp-5-1505-2005, 2005.

Mauldin III, R. L., Berndt, T., Sipilä, M., Paasonen, P., Petäjä, T., Kim, S., Kurtén, T., Stratmann, F., Kerminen, V.-M., and Kulmala, M.: A new atmospherically relevant oxidant of sulphur dioxide, Nature, 488, 193-196, https://doi.org/10.1038/nature11278, 2012.

Mentel, Th. F., Wildt, J., Kiendler-Scharr, A., Kleist, E., Tillmann, R., Dal Maso, M., Fisseha, R., Hohaus, Th., Spahn, H., Uerlings, R., Wegener, R., Griffiths, P. T., Dinar, E., Rudich, Y., and Wahner, A.: Photochemical production of aerosols from real plant emissions, Atmos. Chem. Phys., 9, 4387-4406, https://doi.org/10.5194/acp-9-4387-2009, 2009.

Mikkonen, S., Romakkaniemi, S., Smith, J. N., Korhonen, H., Petäjä, T., Plass-Duelmer, C., Boy, M., McMurry, P. H., Lehtinen, K. E. J., Joutsensaari, J., Hamed, A., Mauldin III, R. L., Birmili, W., Spindler, G., Arnold, F., Kulmala, M., and Laaksonen, A.: A statistical proxy for sulphuric acid concentration, Atmos. Chem. Phys., 11, 11319-11334, https://doi.org/10.5194/acp-1111319-2011, 2011.

Mirme, S. and Mirme, A.: The mathematical principles and design of the NAIS - a spectrometer for the measurement of cluster ion and nanometer aerosol size distributions, Atmos. Meas. Tech., 6, 1061-1071, https://doi.org/10.5194/amt-6-1061-2013, 2013.

Murphy, S. M., Sorooshian, A., Kroll, J. H., Ng, N. L., Chhabra, P., Tong, C., Surratt, J. D., Knipping, E., Flagan, R. C., and Seinfeld, J. H.: Secondary aerosol formation from atmospheric reactions of aliphatic amines, Atmos. Chem. Phys., 7, 2313-2337, https://doi.org/10.5194/acp-7-2313-2007, 2007.

O’Dowd, C. D., Jimenez, J. L., Bahreini, R., Flagan, R. C., Seinfeld, J. H., Hämeri, K., Pirjola, L., Kulmala, M., Jennings, S. G., and Hoffmann, T.: Marine aerosol formation from biogenic iodine emissions, Nature, 417, 632-636, https://doi.org/10.1038/nature00775, 2002.

Paasonen, P., Olenius, T., Kupiainen, O., Kurtén, T., Petäjä, T., Birmili, W., Hamed, A., Hu, M., Huey, L. G., Plass-Duelmer, C., Smith, J. N., Wiedensohler, A., Loukonen, V., McGrath, M. J., Ortega, I. K., Laaksonen, A., Vehkamäki, H., Kerminen, V.-M., 
and Kulmala, M.: On the formation of sulphuric acid - amine clusters in varying atmospheric conditions and its influence on atmospheric new particle formation, Atmos. Chem. Phys., 12, 9113-9133, https://doi.org/10.5194/acp-12-9113-2012, 2012.

Petäjä, T., Mauldin, III, R. L., Kosciuch, E., McGrath, J., Nieminen, T., Paasonen, P., Boy, M., Adamov, A., Kotiaho, T., and Kulmala, M.: Sulfuric acid and $\mathrm{OH}$ concentrations in a boreal forest site, Atmos. Chem. Phys., 9, 7435-7448, https://doi.org/10.5194/acp9-7435-2009, 2009.

Praplan, A. P., Schobesberger, S., Bianchi, F., Rissanen, M. P., Ehn, M., Jokinen, T., Junninen, H., Adamov, A., Amorim, A., Dommen, J., Duplissy, J., Hakala, J., Hansel, A., Heinritzi, M., Kangasluoma, J., Kirkby, J., Krapf, M., Kürten, A., Lehtipalo, K., Riccobono, F., Rondo, L., Sarnela, N., Simon, M., Tomé, A., Tröstl, J., Winkler, P. M., Williamson, C., Ye, P., Curtius, J., Baltensperger, U., Donahue, N. M., Kulmala, M., and Worsnop, D. R.: Elemental composition and clustering behaviour of $\alpha$ pinene oxidation products for different oxidation conditions, Atmos. Chem. Phys., 15, 4145-4159, https://doi.org/10.5194/acp15-4145-2015, 2015.

Riccobono, F., Schobesberger, S., Scott, C. E., Dommen, J., Ortega, I. K., Rondo, L., Almeida, J., Amorim, A., Bianchi, F., Breitenlechner, M., David, A., Downard, A., Dunne, E. M., Duplissy, J., Ehrhart, S., Flagan, R. C., Franchin, A., Hansel, A., Junninen, H., Kajos, M., Keskinen, H., Kupc, A., Kurten, A., Kvashin, A. N., Laaksonen, A., Lehtipalo, K., Makhmutov, V., Mathot, S., Nieminen, T., Onnela, A., Petaja, T., Praplan, A. P., Santos, F. D., Schallhart, S., Seinfeld, J. H., Sipila, M., Spracklen, D. V., Stozhkov, Y., Stratmann, F., Tome, A., Tsagkogeorgas, G., Vaattovaara, P., Viisanen, Y., Vrtala, A., Wagner, P. E., Weingartner, E., Wex, H., Wimmer, D., Carslaw, K. S., Curtius, J., Donahue, N. M., Kirkby, J., Kulmala, M., Worsnop, D. R., and Baltensperger, U.: Oxidation Products of Biogenic Emissions Contribute to Nucleation of Atmospheric Particles, Science, 344, 717-721, https://doi.org/10.1126/science.1243527, 2014.

Riipinen, I., Pierce, J. R., Yli-Juuti, T., Nieminen, T., Häkkinen, S., Ehn, M., Junninen, H., Lehtipalo, K., Petäjä, T., Slowik, J., Chang, R., Shantz, N. C., Abbatt, J., Leaitch, W. R., Kerminen, V.-M., Worsnop, D. R., Pandis, S. N., Donahue, N. M., and Kulmala, M.: Organic condensation: a vital link connecting aerosol formation to cloud condensation nuclei (CCN) concentrations, Atmos. Chem. Phys., 11, 3865-3878, https://doi.org/10.5194/acp-11-3865-2011, 2011.

Rinne, J., Ruuskanen, T., and Reissell, A.: On-line PTR-MS measurements of atmospheric concentrations of volatile organic compounds in a European boreal forest ecosystem, Boreal Environ. Res., 10, 425-436, 2005.

Rissanen, M. P., Kurtén, T., Sipilä, M., Thornton, J. a, Kangasluoma, J., Sarnela, N., Junninen, H., Jørgensen, S., Schallhart, S., Kajos, M. K., Taipale, R., Springer, M., Mentel, T. F., Ruuskanen, T., Petäjä, T., Worsnop, D. R., Kjaergaard, H. G., and Ehn, M.: The formation of highly oxidized multifunctional products in the ozonolysis of cyclohexene, J. Am. Chem. Soc., 136, 1559615606, https://doi.org/10.1021/ja507146s, 2014.

Rondo, L., Kürten, A., Ehrhart, S., Schobesberger, S., Franchin, A., Junninen, H., Petäjä, T., Sipilä, M., Worsnop, D. R., and Curtius, J.: Effect of ions on the measurement of sulfuric acid in the CLOUD experiment at CERN, Atmos. Meas. Tech., 7, 38493859, https://doi.org/10.5194/amt-7-3849-2014, 2014.
Rondo, L., Ehrhart, S., Kürten, A., Adamov, A., Bianchi, F., Breitenlechner, M., Duplissy, J., Franchin, A., Dommen, J., Donahue, N. M., Dunne, E. M., Flagan, R. C., Hakala, J., Hansel, A., Keskinen, H., Kim, J., Jokinen, T., Lehtipalo, K., Leiminger, M., Praplan, A. P., Riccobono, F., Rissanen, M. P., Sarnela, N., Schobesberger, S., Simon, M., Sipilä, M., Smith, J. N., Tomé, A., Tröstl, J., Tsagkogeorgas, G., Vaattovaara, P., Winkler, P. M., Williamson, C., Wimmer, D., Baltensperger, U., Kirkby, J., Kulmala, M., Petäjä, T., Worsnop, D. R., and Curtius, J.: Effect of dimethylamine on the gas phase sulfuric acid concentration measured by Chemical ionization Mass Spectrometry, J. Geophys. Res.-Atmos., 121, 3036-3049, https://doi.org/10.1002/2015JD023868, 2016.

Sarnela, N., Jokinen, T., Nieminen, T., Lehtipalo, K., Junninen, H., Kangasluoma, J., Hakala, J., Taipale, R., Schobesberger, S., Sipilä, M., Larnimaa, K., Westerholm, H., Heijari, J., Kerminen, V.M., Petäjä, T., and Kulmala, M.: Sulphuric acid and aerosol particle production in the vicinity of an oil refinery, Atmos. Environ., 119, 156-166, https://doi.org/10.1016/j.atmosenv.2015.08.033, 2015.

Sarnela, N., Jokinen, T., Duplissy, J., Yan, C., Nieminen, T., Ehn, M., Schobesberger, S., Heinritzi, M., Ehrhart, S., Lehtipalo, K., Tröstl, J., Simon, M., Kürten, A., Leiminger, M., Lawler, M. J.; Rissanen, M. P.; Bianchi, F., Praplan, A. P.; Hakala, J., Amorin, A., Gonin, M., Hansel, A., Kirkby, J., Dommen, J., Curtius, J., Smith, J. N., Petäjä, T., Worsnop, D. R., Kulmala, M., Donahue, N. M., and Sipilä, M.: Measurement-model comparison of stabilized Criegee intermediate and highly oxygenated molecule production in the CLOUD chamber, Data set, https://doi.org/10.5281/zenodo.1170108, 2018.

Seinfeld, J. H. and Pankow, J. F.: Organic atmospheric particulate material, Annu. Rev. Phys. Chem., 54, 121-140, https://doi.org/10.1146/annurev.physchem.54.011002.103756, 2003.

Sihto, S.-L., Kulmala, M., Kerminen, V.-M., Dal Maso, M., Petäjä, T., Riipinen, I., Korhonen, H., Arnold, F., Janson, R., Boy, M., Laaksonen, A., and Lehtinen, K. E. J.: Atmospheric sulphuric acid and aerosol formation: implications from atmospheric measurements for nucleation and early growth mechanisms, Atmos. Chem. Phys., 6, 4079-4091, https://doi.org/10.5194/acp-6-40792006, 2006.

Sipilä, M., Jokinen, T., Berndt, T., Richters, S., Makkonen, R., Donahue, N. M., Mauldin III, R. L., Kurtén, T., Paasonen, P., Sarnela, N., Ehn, M., Junninen, H., Rissanen, M. P., Thornton, J., Stratmann, F., Herrmann, H., Worsnop, D. R., Kulmala, M., Kerminen, V.-M., and Petäjä, T.: Reactivity of stabilized Criegee intermediates (sCIs) from isoprene and monoterpene ozonolysis toward $\mathrm{SO}_{2}$ and organic acids, Atmos. Chem. Phys., 14, $12143-$ 12153, https://doi.org/10.5194/acp-14-12143-2014, 2014.

Sipilä, M., Sarnela, N., Jokinen, T., Henschel, H., Junninen, H., Kontkanen, J., Richters, S., Kangasluoma, J., Franchin, A., Peräkylä, O., Rissanen, M. P., Ehn, M., Vehkamäki, H., Kurten, T., Berndt, T., Petäjä, T., Worsnop, D., Ceburnis, D., Kerminen, V.-M., Kulmala, M., and O'Dowd, C.: Molecular-scale evidence of aerosol particle formation via sequential addition of $\mathrm{HIO}_{3}$, Nature, 537, 532-534, https://doi.org/10.1038/nature19314, 2016.

Steiner, G., Attoui, M., Wimmer, D., and Reischl, G. P.: A Medium Flow, High-Resolution Vienna DMA Running 
in Recirculating Mode, Aerosol Sci. Tech., 44, 308-315, https://doi.org/10.1080/02786821003636763, 2010.

$\mathrm{Su}, \mathrm{T}$. and Bowers, M. T.: Ion-polar molecule collisions - effect of molecular size on ion-polar molecule rate constants, J. Am. Chem. Soc, 95, 7609-7610, 1973.

Taatjes, C. A., Welz, O., Eskola, A. J., et al.: Direct measurements of conformer-dependent reactivity of the Criegee intermediate CH3CHOO., Science, 340, 177-180, https://doi.org/10.1126/science.1234689, 2013.

Tröstl, J., Chuang, W. K., Gordon, H., Heinritzi, M., Yan, C., Molteni, U., Ahlm, L., Frege, C., Bianchi, F., Wagner, R., Simon, M., Lehtipalo, K., Williamson, C., Craven, J. S., Duplissy, J., Adamov, A., Almeida, J., Bernhammer, A.-K., Breitenlechner, M., Brilke, S., Dias, A., Ehrhart, S., Flagan, R. C., Franchin, A., Fuchs, C., Guida, R., Gysel, M., Hansel, A., Hoyle, C. R., Jokinen, T., Junninen, H., Kangasluoma, J., Keskinen, H., Kim, J., Krapf, M., Kürten, A., Laaksonen, A., Lawler, M., Leiminger, M., Mathot, S., Möhler, O., Nieminen, T., Onnela, A., Petäjä, T., Piel, F. M., Miettinen, P., Rissanen, M. P., Rondo, L., Sarnela, N., Schobesberger, S., Sengupta, K., Sipilä, M., Smith, J. N., Steiner, G., Tomè, A., Virtanen, A., Wagner, A. C., Weingartner, E., Wimmer, D., Winkler, P. M., Ye, P., Carslaw, K. S., Curtius, J., Dommen, J., Kirkby, J., Kulmala, M., Riipinen, I., Worsnop, D. R., Donahue, N. M., and Baltensperger, U.: The role of low-volatility organic compounds in initial particle growth in the atmosphere, Nature, 533, 527-531, https://doi.org/10.1038/nature18271, 2016.

Vereecken, L., Harder, H., and Novelli, A.: The reaction of Criegee intermediates with $\mathrm{NO}, \mathrm{RO}_{2}$, and $\mathrm{SO}_{2}$, and their fate in the atmosphere, Phys. Chem. Chem. Phys., 14, 14682-14695, https://doi.org/10.1039/c2cp42300f, 2012.

Vereecken, L., Harder, H., and Novelli, A.: The reactions of Criegee intermediates with alkenes, ozone, and carbonyl oxides, Phys. Chem. Chem. Phys., 16, 4039-4049, https://doi.org/10.1039/c3cp54514h, 2014.

Voigtländer, J., Duplissy, J., Rondo, L., Kürten, A., and Stratmann, F.: Numerical simulations of mixing conditions and aerosol dynamics in the CERN CLOUD chamber, Atmos. Chem. Phys., 12, 2205-2214, https://doi.org/10.5194/acp-12-2205-2012, 2012.
Wang, S. C. and Flagan, R. C.: Scanning Electrical Mobility Spectrometer, Aerosol Sci. Tech., 13, 230-240, https://doi.org/10.1080/02786829008959441, 1990.

Weber, R. J., Marti, J. J., McMurry, P. H., Eisele, F. L., Tanner, D. J., and Jefferson, A.: Measured atmospheric new particle formation rates: implications for nucleation mechanisms, Chem. Eng. Commun., 151, 53-64, https://doi.org/10.1080/00986449608936541, 1996.

Weber, R. J., Marti, J. J., McMurry, P. H., Eisele, F. L., Tanner, D. J., and Jefferson, A.: Measurements of new particle formation and ultrafine particle growth rates at a clean continental site, J. Geophys. Res., 102, 4375-4385, https://doi.org/10.1029/96JD03656, 1997.

Wehner, B., Petäjä, T., Boy, M., Engler, C., Birmili, W., Tuch, T., Wiedensohler, A., and Kulmala, M.: The contribution of sulfuric acid and non-volatile compounds on the growth of freshly formed atmospheric aerosols, Geophys. Res. Lett., 32, L17810, https://doi.org/10.1029/2005GL023827, 2005.

Welz, O., Savee, J. D., Osborn, D. L., Vasu, S. S., Percival, C. J., Shallcross, D. E., and Taatjes, C. A.: Direct kinetic measurements of Criegee intermediate $\left(\mathrm{CH}_{2} \mathrm{OO}\right)$ formed by reaction of $\mathrm{CH}_{2} \mathrm{I}$ with $\mathrm{O}_{2}$, Science, 335, 204-207, https://doi.org/10.1126/science.1213229, 2012.

Yan, C., Nie, W., Äijälä, M., Rissanen, M. P., Canagaratna, M. R., Massoli, P., Junninen, H., Jokinen, T., Sarnela, N., Häme, S. A. K., Schobesberger, S., Canonaco, F., Yao, L., Prévôt, A. S. H., Petäjä, T., Kulmala, M., Sipilä, M., Worsnop, D. R., and Ehn, M.: Source characterization of highly oxidized multifunctional compounds in a boreal forest environment using positive matrix factorization, Atmos. Chem. Phys., 16, 12715-12731, https://doi.org/10.5194/acp-16-12715-2016, 2016.

Yao, L., Ma, Y., Wang, L., Zheng, J., Khalizov, A., Chen, M., Zhou, Y., Qi, L., and Cui, F.: Role of stabilized Criegee Intermediate in secondary organic aerosol formation from the ozonolysis of $\alpha$-cedrene, Atmos. Environ., 94, 448-457, https://doi.org/10.1016/j.atmosenv.2014.05.063, 2014. 